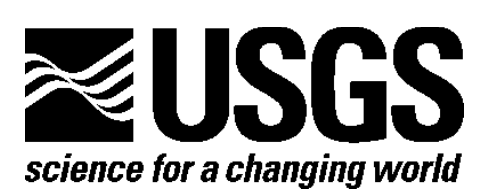

\title{
Geologic and Geophysical Data for Wells Drilled at Raft River Valley, Cassia County, Idaho, in 1977-1978 and Data for Wells Drilled Previously
}

By Manuel Nathenson, Thomas C. Urban, and Harry R. Covington

Open-File Report 2014-1201

U.S. Department of the Interior

U.S. Geological Survey 


\section{U.S. Department of the Interior \\ SALLY JEWELL, Secretary}

\section{U.S. Geological Survey \\ Suzette M. Kimball, Acting Director}

U.S. Geological Survey, Reston, Virginia: 2014

For product and ordering information:

World Wide Web: http://www.usgs.gov/pubprod

Telephone: 1-888-ASK-USGS

For more information on the USGS—-the Federal source for science about the Earth, its natural and living resources, natural hazards, and the environment:

World Wide Web: http://www.usgs.gov

Telephone: 1-888-ASK-USGS

Suggested citation:

Nathenson, M., Urban, T.C., and Covington, H.R., 2014, Geologic and geophysical data for wells drilled at Raft River Valley, Cassia County, Idaho, in 1977-1978 and data for wells drilled previously: U.S. Geological Survey Open-File Report 2014-1201, 30 p., http://dx.doi.org/10.3133/ofr20141201.

Any use of trade, product, or firm names is for descriptive purposes only and does not imply endorsement by the U.S. Government.

Although this information product, for the most part, is in the public domain, it also may contain copyrighted materials as noted in the text. Permission to reproduce copyrighted items must be secured from the copyright owner.

ISSN 2331-1258 (online) 


\section{Contents}

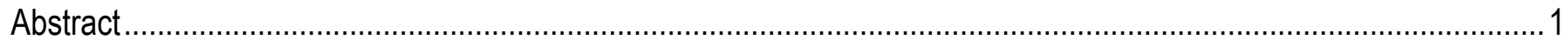

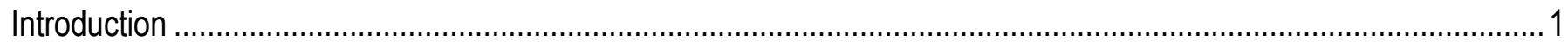

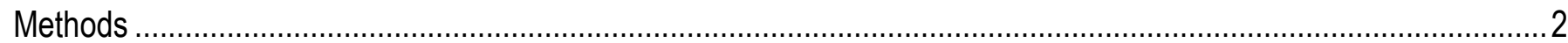

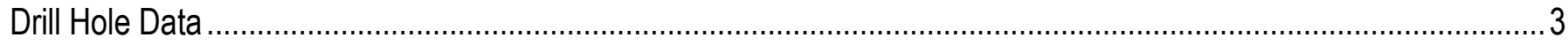

Temperatures in Drill Holes by Area

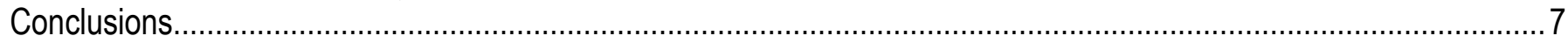

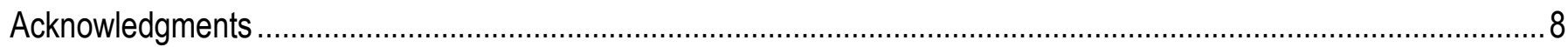

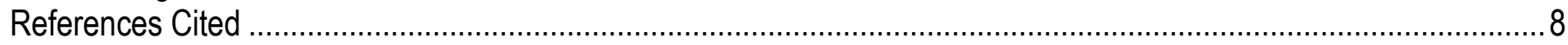

Appendix A. Lithologic, geophysical, and temperature logs for $\mathrm{H}$-series of wells

Appendix B. Temperature logs for other wells

[Appendixes are available for download at http://pubs.usgs.gov/of/2014/1201]

\section{Figures}

1. Photograph of drilling rig on well H01 with 4 1/2-inch diameter drill bit (August 21, 1977) .....................9

2. Photograph of logging truck with cable in well (1979) ................................................................... 10

3. Photograph showing logging of well I.D.3 with stand pipe and packing gland on top

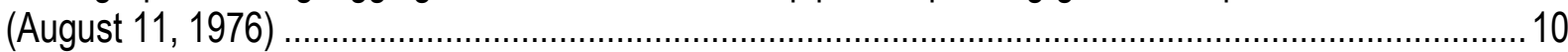

4. $\quad$ Map showing locations for drill holes reported in this study, Raft River Valley, Idaho .........................11

5. Diagram of letter codes designating parts of sections for the location data given in table 1................12

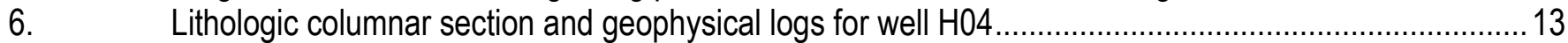

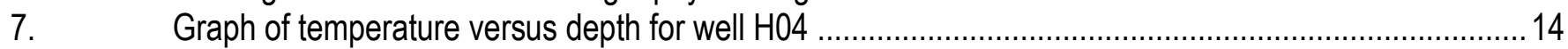

8. Map of locations of drill holes along with representative temperature gradients (in ${ }^{\circ} \mathrm{C} / \mathrm{km}$ ) listed

before well name, Raft River Valley, Idaho ...................................................................................... 15

9. Map of locations of drill holes in Raft River Valley, Idaho, showing areas for plots of temperature versus depth (figs. 10-16) along with representative temperature gradients ......................................16

10. Graph of temperature versus depth for drill holes in the northwest part of the Raft River Valley ...........17

11. Data for drill holes in the eastern part of the Raft River Valley ....................................................... 18

12. Graph of temperature versus depth for drill holes north of the deep well area, Raft River Valley ..........20

13. Graph of temperature versus depth for drill holes in the deep well area, Raft River Valley....................21

14. Data for wells in the Narrows area, Raft River Valley...................................................................22

15. Graph of temperature versus depth and temperature gradient for drill holes between The Narrows

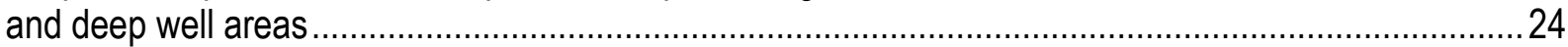

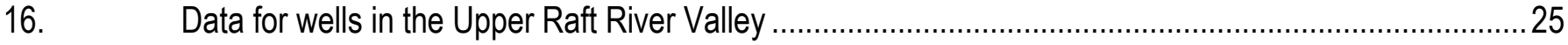

\section{Tables}

1. Locations of drill holes reported in this study. 27

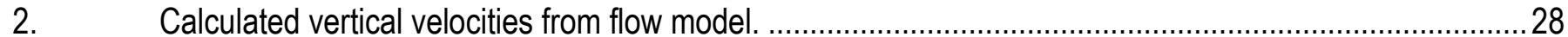

3. Thermal conductivites, temperature gradients, and heat flow for wells at Raft River, Idaho ....................28

4. Representative temperature gradients for wells at Raft River, Idaho .............................................29 


\section{Conversion Factors}

[Inch/Pound to SI]

\begin{tabular}{ccl}
\hline Multiply & By & To obtain \\
\hline foot $(\mathrm{ft})$ & 0.3048 & meter $(\mathrm{m})$ \\
\hline
\end{tabular}

Temperature in degrees Celsius $\left({ }^{\circ} \mathrm{C}\right)$ may be converted to degrees Fahrenheit $\left({ }^{\circ} \mathrm{F}\right)$ as follows: ${ }^{\circ} \mathrm{F}=\left(1.8 \times{ }^{\circ} \mathrm{C}\right)+32$

Vertical coordinate information is referenced to the North American Datum of 1927 (NAD 27).

Horizontal coordinate information is referenced to the North American Datum of 1927 (NAD 27).

Altitude, as used in this report, refers to distance above the vertical datum. 


\title{
Geologic and Geophysical Data for Wells Drilled at Raft River Valley, Cassia County, Idaho, in 1977-1978 and Data for Wells Drilled Previously
}

\author{
By Manuel Nathenson, Thomas C. Urban, and Harry R. Covington
}

\begin{abstract}
In order to better define the size of the thermal anomaly in the Raft River Valley, Idaho, the U.S. Geological Survey drilled a series of intermediate-depth (nominal 500-ft depth) wells in 1977 and 1978. This report presents geologic, geophysical, and temperature data for these drill holes, along with data for five wells drilled by the Idaho National Engineering Laboratory with U.S. Department of Energy funding. Data previously reported for other drill holes are also included in order to make them available as digital files.

For purposes of defining the thermal anomaly for the geothermal system, temperature gradients are calculated over long depth intervals on the basis of the appearance of reasonably linear segments on a temperature versus depth plot. Temperature versus depth data for some drill holes can be represented by a single gradient, whereas others require multiple gradients to match the data. Data for some drill holes clearly reflect vertical flows of water in the formation surrounding the drill holes, and water velocities are calculated for these drill holes. Within The Narrows area, temperature versus depth data show reversals at different depths in different drill holes. In the main thermal area, temperatures in intermediate-depth drill holes vary approximately linearly but with very high values of temperature gradient. Temperature gradients on a map of the area can be reasonably divided into a large area of regional gradients and smaller areas defining the thermal anomalies.
\end{abstract}

\section{Introduction}

The Idaho geothermal project was started in 1973 under Aerojet Nuclear Company at the National Reactor Testing Station with funding from the U.S. Atomic Energy Commission (Kunze and Miller, 1974). The purpose of the project was to develop the geothermal resource in the Raft River Valley for the generation of electricity. U.S. Geological Survey (USGS) investigators did earth science studies of geology, geophysics, hydrology, and water chemistry and drilled auger holes and intermediate-depth core holes. Work continued on the project at the renamed Idaho National Engineering Laboratory with funding from successor agencies: the Energy Research and Development Administration and then the U.S. Department of Energy. Results of the earth science studies were reported in Williams and others (1976), Mabey and others (1978), Ackermann (1979), Keys and Sullivan (1979), Nathenson and others (1980, 1982), and Urban and others (1986). Seven deep production and injection wells were drilled (Dolenc and others, 1981), and a 5-megawatt electric binary-cycle power plant was installed and 
operated in 1981 and 1982 and shut down in 1982 (Bleim, 1983). The property was acquired by U.S. Geothermal in 2002, and a 13-megawatt power plant was constructed and brought on line in 2007 (Bradford and others, 2013).

In order to better define the size of the thermal anomaly, the USGS drilled a series of intermediate-depth wells in 1977 and 1978 with funding from the USGS Geothermal Research Program. The wells were completed with cemented casing in order to prevent water flows within the drill holes. Because data for the wells have not been previously published, this report now presents geologic, geophysical, and temperature data for these drill holes. In addition, data not previously published are reported for five wells drilled by the Idaho National Engineering Laboratory with U.S. Department of Energy funding. Data for wells previously reported by Urban and others (1986) are also included in order to make them available now in digital form. This report contains a summary discussion of the data, and the complete data files are included as appendixes. The data from all wells are used to define the areas of thermal anomalies.

\section{Methods}

The twenty-four wells designated the $\mathrm{H}$ series were drilled to 80 feet with a diameter of $7 \%$ inch using a rotary drilling rig. Welded casing 5 inches in diameter was placed in the well. Cement was mixed onsite, pumped down the casing, and followed by a wiper plug and water. The casing plug was drilled out with $41 / 2$-inch-diameter drill bit, and drilling was continued to a nominal 500 feet (fig. 1). Drill cuttings were collected every 5 feet and used to develop lithologic logs. Geophysical logs were run using one tool for caliper and resistivity and a second tool for natural gamma ray, with the data recorded on chart paper. Resistivity logs were calibrated using a calibration box, and caliper logs with a jig at 4,6, and 8 inches to hold the caliper arms. Gamma ray logs were recorded as counts per second, with a calibration recorded at 200 American Petroleum Institute (API) units. All logs on chart paper were digitized at a later date. The resistivity logs were digitized using an arbitrary100-count scale along with the nonlinear resistance calibration recorded on the same scale. The resistance calibration is in ohms, and the relation of the resistance in ohms to the formation resistivity in ohm meters is unknown. After logging was completed, threaded casing of 2-inch diameter was placed in the hole with joint compound on the threads. Cement was pumped down the casing followed by a latching wiper plug and water. Drill hole H06 did not have 2-inch casing installed because it became artesian, and well $\mathrm{H} 41$ did not have 2-inch casing installed because time ran out at the end of the drilling program. Inclinometer measurements were made at discrete depths using hydrofluoric acid in small test tubes and are reported in appendix A.

Methods of measuring temperature versus depth evolved over the time period of logging wells at Raft River. The earliest measurements were made by stopping at discrete depths and recording the resistance of the thermistor attached to a four-conductor cable. The next step was logging at a fixed speed (fig. 2), with resistances recorded at specified depths using a teletype with paper tape. The final configuration was logging at a fixed speed with resistances converted to temperature in a Tektronix ${ }^{\circledR} 4051$ computer and recorded on paper tape. Plots of temperature versus depth show the recorded data points as individual points. Further details of logging methods and calibration are given in Urban and others (1987). For wells that had pressure at the wellhead, pipes and a packing gland were added to keep the well from flowing (fig. 3). 


\section{Drill Hole Data}

Locations of wells with data reported in this study are shown in figure 4 , and location, depth, and drilling-date information are given in table 1, with letter codes for the location data in figure 5. Data for these wells, along with data for the auger holes reported in Urban (1986), are given in the appendixes. Wells drilled for this study are the H series, and the wells contracted by the Idaho National Engineering Laboratory are the HF series. Additional wells listed are those drilled earlier by the USGS (Crosthwaite, 1976), the deep wells in the RRGE series, and various other wells drilled by others that we were allowed to make temperature measurements in.

Geologic and geophysical data were collected along with temperature logs to select appropriate depths for measurement of thermal conductivity. Although we were not able to measure thermal conductivities, it is worth exploring detailed relationships between lithology and geophysical logs, and figure 6 shows these data for well H04. The lithology is sedimentary, with layers of siltstone, claystone, and conglomerate. The natural gamma-ray and resistance logs have a fair amount of variation, with layers of high and low values in each. There is no obvious relation between the lithologic character of the cuttings and the natural gamma-ray and resistance logs. The relation between the natural gamma-ray and resistance logs appears to change below a depth of around $450 \mathrm{ft}$. Above this depth, they seem to vary independently, whereas below this depth they appear to track together in that an increase (or decrease) in the values for one corresponds to an increase (or decrease) in the other. The temperature gradient values systematically decrease from $\sim 80^{\circ} \mathrm{C} / \mathrm{km}$ to $\sim 60{ }^{\circ} \mathrm{C} / \mathrm{km}$ from a depth of about $90 \mathrm{ft}$ to $300 \mathrm{ft}$. Such a systematic decrease is not reflected in any trend in either the lithology or the geophysical logs, and it most likely reflects vertical flow of water in the surrounding rocks (see discussion below). Below 450-ft depth, there are alternating layers of high and low temperature gradient values. There does seem to be a correspondence between the alternating layers in the temperature gradient values and changes in the geophysical log values. If one were sampling for thermal conductivity measurements, these alternating layers would be worth sampling to check whether the heat flow is constant through this lower part of the section. The upper $300 \mathrm{ft}$, with its water flow, would not be very good for assessing the deeper heat flow.

The theory for the effect of a vertical flow of water on temperatures was developed by Bredehoeft and Papadopulos (1965). For a layer with a temperature $T_{0}$ at the top and $T_{L}$ at the bottom with water flowing at velocity $v$ downwards, the temperature distribution is:

$$
\begin{aligned}
& \frac{T-T_{0}}{T_{L}-T_{0}}=\left[\exp \left(\frac{\beta z}{L}\right)-1\right] /[\exp (\beta)-1] \\
& \beta=\rho_{w} c_{w} v L / k
\end{aligned}
$$

where $z$ is depth, $\rho_{w}$ and $c_{w}$ are, respectively, the density and specific heat of water, $L$ is the length of the layer, and $k$ is the thermal conductivity of the formation. Differentiating this result, the temperature gradient is:

$$
\frac{d T}{d z}=\left(T_{L}-T_{0}\right) \frac{\beta}{L} \exp \left(\frac{\beta z}{L}\right) /[\exp (\beta)-1] .
$$

Thus, plotting the temperature gradient on a log scale versus a linear scale for depth results in straight-line behavior. The temperature gradient for well H04 is a linear function of depth on a 
$\log$ scale from about 93 to $295 \mathrm{ft}$, with some variation about this linear dependence (fig. 6). The estimated velocity is $-0.026 \mathrm{~m} / \mathrm{y}$. The curvature in the profile (fig. 7) is not large, but for other wells discussed below, it is much stronger, and their flow velocities are larger in magnitude (table 2).

Thermal conductivities were measured for a number of wells at Raft River (table 3), and the data are plotted in Nathenson and others (1980) and Urban and others (1986). Measurements were done using the needle-probe technique, which tends to result in significant scatter in values (Urban and others, 1986). This is reflected in the large values for the standard deviation given in table 3, a better measure of the uncertainty than the standard error (the large number of measurements results in small values that are misleading). Despite the large uncertainties, a considerable range in values for thermal conductivity is evident from the four wells. Well I.D. 5 has a significant amount of quartz monzonite in brecciated blocks or as part of conglomerate (Crosthwaite, 1976; H.R. Covington, written commun., 1977). Temperatures for well I.D. 5A (near I.D. 5 but deeper) are given in figure 10, and there are two zones of differing gradients. Heat flows calculated with the two gradients and average thermal conductivities differ by 10 percent (table 3). Thermal conductivities in the three other wells are significantly lower. Because these three wells are in the thermal area (see below), the temperature gradients and heat flows have a wide range and cannot be used to judge whether one value of thermal conductivity is more representative of the sediments in the valley than another. Urban and others (1986) chose amongst the values in table 3 to calculate heat flows for other wells, but we shall use temperature gradients instead.

Although the detailed variations discussed above are interesting, they are not very helpful without measurements of thermal conductivity. For purposes of defining the thermal anomaly for the geothermal system, we will focus on temperature gradients calculated over longer depth intervals based on the appearance of reasonably linear segments chosen by eye on a temperature versus depth plot. Figure 7 shows the selected temperature gradients in well H04. The temperature gradients over long depth intervals miss the detailed variations in figure 6 , but they are reasonably representative.

Estimates of such representative gradients are provided in table 4 and shown on a map of drill hole locations in figure 8 . The temperature versus depth data for some drill holes are reasonably represented by a single gradient, whereas others require two gradients. The map showing temperature gradients can be reasonably divided into a large area of regional gradients and smaller areas defining the thermal anomalies. The thermal anomalies are defined as having a temperature gradient $>70{ }^{\circ} \mathrm{C} / \mathrm{km}$. The basis for the contours is further developed in the next section. The area of the main thermal anomaly is shown open towards the Jim Sage Mountains, as no thermal data constrain its extent in that direction. The thermal anomaly at Almo 1 is shown as a small area also open towards the Jim Sage Mountains.

\section{Temperatures in Drill Holes by Area}

Figure 9 repeats the temperature gradients from figure 8 and outlines areas with the figure numbers for the following plots of temperature versus depth. Figure 10 shows data for I.D. 5A and other drill holes in the northwest part of the Raft River Valley. Well I.D. 5 was drilled to a depth of $718 \mathrm{ft}$ to measure regional heat flow (Nathenson and others, 1980), and well I.D. 5A was drilled nearby to a depth of $1,197 \mathrm{ft}$ to assess if the temperature gradient continued to greater depth. The gradients from $500 \mathrm{ft}$ to total depth are $44.2^{\circ} \mathrm{C} / \mathrm{km}$ in I.D. 5 and $44.9^{\circ} \mathrm{C} / \mathrm{km}$ in I.D. 
5A, essentially the same. Drill hole $\mathrm{H} 05$ has a somewhat erratic profile, but the overall gradient of $56{ }^{\circ} \mathrm{C} / \mathrm{km}$ (table 4) is somewhat less than the upper gradient of $64{ }^{\circ} \mathrm{C} / \mathrm{km}$ in I.D. 5A. The bottom section of $\mathrm{H} 05$ has a gradient of $176^{\circ} \mathrm{C} / \mathrm{km}$ from 488 to $500 \mathrm{ft}$, and this very high gradient probably reflects a water flow. Drill hole H03 has an irregular temperature versus depth profile, with three reasonably linear sections (table 4) and a nonlinear section at about $300-\mathrm{ft}$ depth. Temperature gradients in the upper part of the profile are 56 and $70{ }^{\circ} \mathrm{C} / \mathrm{km}$, but from 440 to $508 \mathrm{ft}$, the gradient is $95{ }^{\circ} \mathrm{C} / \mathrm{km}$. This latter gradient is similar to the gradient in drill hole $\mathrm{H} 07$ of $89{ }^{\circ} \mathrm{C} / \mathrm{km}$, which is clearly much steeper than the other drill holes in this group (fig. 10). Drill hole H04 (fig. 7, discussed above) has an upper gradient of $72{ }^{\circ} \mathrm{C} / \mathrm{km}$ and a deeper gradient of $53{ }^{\circ} \mathrm{C} / \mathrm{km}$. Drill hole $\mathrm{H} 08$ has a gradient of $65^{\circ} \mathrm{C} / \mathrm{km}$. Comparing the temperature versus depth plots for the various drill holes in figure 10, some of the temperature gradients are quite variable, but the temperatures at a given depth group reasonably together. Drill hole H07 is clearly warmer, with a consistent gradient of $89^{\circ} \mathrm{C} / \mathrm{km}$, and appears to define the boundary of the thermal anomaly. The gradients for well H06 are also high (table 4), but the well is shallow, has only surface casing, and is under artesian pressure. The well is in a saddle between the Jim Sage Mountains and Sheep Mountain just to the east, and the gradients are assumed to be influenced by hydrology. The Jim Sage Mountains are to the west of these drill holes (fig. 9), and there is significant topographic relief to drive water flows in the subsurface. Some of the changes in temperature gradient could well be related to horizontal flows of water, and the temperatures in well H04 demonstrate vertical flow of water.

Drill holes in the eastern part of the Raft River Valley (fig. 9) are generally cool (fig. $11 A$ ) and define the eastern extent of the thermal anomaly. Well H15 has a low gradient of $45^{\circ} \mathrm{C} / \mathrm{km}$. Well $\mathrm{H} 17$ has two gradients of 43 and $66^{\circ} \mathrm{C} / \mathrm{km}$, and the latter gradient is similar to the gradient of $68{ }^{\circ} \mathrm{C} / \mathrm{km}$ in well $\mathrm{H} 18$. The temperatures in $\mathrm{H} 17$ and $\mathrm{H} 18$ are similar (fig. 11A). Wells H01 and H16 have strongly nonlinear temperature gradients (fig. 11B). This behavior reflects vertical flow of water downward in the surrounding rock as indicated by straight-line variation with depth of the log of the temperature gradient (fig. 11B). The straight-line fits to the $\log$ of the temperature gradient versus depth (fig. $11 B$ ) are pretty good matches. The velocity of water flow is $0.12 \mathrm{~m} / \mathrm{y}$ in $\mathrm{H} 01$ and $0.072 \mathrm{~m} / \mathrm{y}$ in H16 (downward). This would indicate groundwater recharge in the vicinity of the wells.

Although it does not appear that the wells are deep enough to get beyond the downward water flow, estimates of overall gradients are obtained by taking a temperature at depth where the straight-line behavior starts and a temperature at the total depth of the wells. These estimated gradients are $46{ }^{\circ} \mathrm{C} / \mathrm{km}$ in $\mathrm{H} 01$ and $43{ }^{\circ} \mathrm{C} / \mathrm{km}$ in $\mathrm{H} 16$, and the values are shown on figures 8 and 9. The overall temperature gradients in these wells are quite similar to that in $\mathrm{H} 15$ of $45^{\circ} \mathrm{C} / \mathrm{km}$.

The reasons for the variations about the straight-line behavior of the log of the temperature gradients for wells H01 and H16 (fig. 11B) are not clear. For well H01, most but not all of the variations in gradient shown in figure $11 B$ also occur when plotting temperature gradients from the temperature log of July 30, 1979 (not shown). Thus the variations in gradient either reflect some variation with depth in the thermal regime in the surrounding rock or some variation caused by the influence of the drill hole completion. Although the casing was cemented from bottom to top, we have no measures to demonstrate that the cement prevents small flows of water over short distances. The casing joints used were $21 \mathrm{ft}$ in length, and the wavelength of some of the anomalies are of that order. For some of the variations in well H01, the gradient first increases and then decreases with increasing depth. This is not to be expected if there were enhanced downward flow, and this behavior may indicate a small upward flow imposed on the 
temperature profile for downward flow in the formation. Given that these drill holes were completed using methods designed for high-quality measurements of temperature versus depth, these unexplained variations, noticeable because of the high precision of the temperature measurements, may reflect our inability to stop small variations caused by imperfect drill hole completion.

Temperature gradients in the area just to the north of the deep wells RRGE 1, 2, and 3 (fig. 9) are significantly higher than those in areas farther north and to the east. Temperature gradients are $89{ }^{\circ} \mathrm{C} / \mathrm{km}$ in $\mathrm{H} 07$ and 88 and $78{ }^{\circ} \mathrm{C} / \mathrm{km}$ in upper and lower parts of $\mathrm{H} 02$.

Temperatures are higher in wells HF1 and HF2 (fig. 12), as are the temperature gradients (fig. 9). The temperature profiles in HF1 and HF2 may reflect water flows within the annulus between the casing and drill hole, because cement was probably added only from above. Well I.D. 1 has rather variable temperature gradients but becomes warmer than $\mathrm{H} 02$ and $\mathrm{H} 07$ below $350 \mathrm{ft}$. Notable but small jumps in temperature in well H02 occur at depths of 288, 330, 372, and $414 \mathrm{ft}$. In each case, the difference in depth between the jumps is $42 \mathrm{ft}$ or two casing lengths. The calibrated inclinometer angle from vertical is $4.8^{\circ}$ at $260 \mathrm{ft}, 9.5^{\circ}$ at $360 \mathrm{ft}$, and $7.9^{\circ}$ at $460 \mathrm{ft}$, and it seems likely that the sinker bar above the temperature probe was sliding along the casing. It would appear that the sinker bar was slightly hanging up at some of the casing joints, reducing the tension in the cable, and then being released from the impediment and falling and retensioning the cable to rapidly increase the temperature. However, the temperature jumps range from 0.1 to $0.14{ }^{\circ} \mathrm{C}$. The amount that would happen from lowering the cable along the temperature gradient by $2 \mathrm{ft}$ is $0.05^{\circ} \mathrm{C}$, and the extra temperature increase represents the probe dropping an additional 2 to 4 feet. The amount of slack before the cable goes completely slack in the logging truck at these depths in 2-in casing is probably only 2 feet and may not be as large as $4 \mathrm{ft}$.

Temperature gradients in the area of the deep wells RRGE 1, 2, and 3 (fig. 9) are quite high. The highest temperatures are in Shuter's Hot Well (SHW), reaching nearly $94{ }^{\circ} \mathrm{C}$ at $402 \mathrm{ft}$ (fig. 13). Well H09, about 3,000 ft northwest and about $100 \mathrm{ft}$ higher in elevation, has a somewhat lower gradient, and temperatures reach $44.4^{\circ} \mathrm{C}$ at $548 \mathrm{ft}$. Similar to Shuter's Hot Well, H09 has nearly isothermal temperatures in the bottom part of the well. Wells I.D. 2 and I.D. 3 also have high gradients (fig. 9) and temperatures (fig. 13). To the southeast, well HF3 has a lower gradient and well $\mathrm{H} 14$ has a gradient that is approximately regional in value $\left(56^{\circ} \mathrm{C} / \mathrm{km}\right)$.

Temperatures in The Narrows area (fig. 14A) show the effect of horizontal flow of warm water. Well I.D. 4 has a temperature of $42.5^{\circ} \mathrm{C}$ at $80 \mathrm{ft}$. The form of the profile indicates that either the flow of warm water started at a relatively recent time (see, for example, Ziagos and Blackwell, 1986) or that the flow overlies a flow of cooler water to explain the temperature reversal. Auger Hole A.H. 13-N is about $500 \mathrm{ft}$ north of wells $\mathrm{H} 10$ and $\mathrm{H} 30$ and has a temperature of $78.3{ }^{\circ} \mathrm{C}$ at a depth of $51 \mathrm{ft}$. Wells $\mathrm{H} 10$ and $\mathrm{H} 30$ are immediately adjacent to each other. Well $\mathrm{H} 30$ was drilled to try to get below the temperature reversal, but the reversal continued to total depth of $898 \mathrm{ft}$. The temperature profiles in $\mathrm{H} 10$ and $\mathrm{H} 30$ are broadly similar. The maximum temperature in $\mathrm{H} 10$ is $67.1^{\circ} \mathrm{C}$ at a depth of $325 \mathrm{ft}$, and that in $\mathrm{H} 30$ is $71.5^{\circ} \mathrm{C}$ at a depth of $364 \mathrm{ft}$. The reason for the difference in temperature and depth of maximum temperature is unclear. The upper part of the profile in H30 suggests water flows from incompletely cemented casing. Both wells intercept rhyolite lava flows below $260 \mathrm{ft}$. The varying depths and values of maximum temperatures indicate that the fluid-flow system is quite complex.

Temperatures for the cooler wells in The Narrows are shown in figure 14B, along with temperature gradients for $\mathrm{H} 11$ and $\mathrm{H} 12$ on a log scale. The temperature gradient in the upper part 
of $\mathrm{H} 12$ is $171{ }^{\circ} \mathrm{C} / \mathrm{km}$. The lower part has an upward flow of water as shown by the curvature in the temperature versus depth plot (fig. 14B), and the plot of the log of the temperature gradient versus depth is linear from 195 to $517 \mathrm{ft}$, confirming this behavior. The vertical velocity is -0.13 $\mathrm{m} / \mathrm{y}$ (upwards). The temperature gradient in the lower part of $\mathrm{H} 12$ is $75^{\circ} \mathrm{C} / \mathrm{km}$. Well H35 has a temperature gradient of $164{ }^{\circ} \mathrm{C} / \mathrm{km}$. Temperatures in $\mathrm{H} 12$ and $\mathrm{H} 35$ are similar, though $\mathrm{H} 35$ is hotter near its bottom. Representative temperature gradients in the middle and lower parts of $\mathrm{H} 11$ are 120 and $100{ }^{\circ} \mathrm{C} / \mathrm{km}$, respectively. The temperature profile in well $\mathrm{H} 11$ shows both a downflow of water in its middle part and an upflow in its lower part (fig. 14B). The velocity in the upper part of $\mathrm{H} 11$ is $0.094 \mathrm{~m} / \mathrm{y}$ and in the lower part $-0.23 \mathrm{~m} / \mathrm{y}$. Thus the upward flow in the bottom part of H11 and the downward flow in the middle depth range exit at a depth of around $400 \mathrm{ft}$ and become a horizontal flow of water. This depth coincides with the bottom of the brecciated zone at the top of the rhyolite lava flow (fig. A-46) and with the depth where resistance and natural gamma-ray values increase (fig. A-48). Well H13 has temperature gradients of 48 and $97^{\circ} \mathrm{C} / \mathrm{km}$ in the middle and lower parts, respectively, and an overall gradient of $73{ }^{\circ} \mathrm{C} / \mathrm{km}$. Temperatures in $\mathrm{H} 11$ and $\mathrm{H} 13$ are less than in $\mathrm{H} 35$ and $\mathrm{H} 12$, and the lower temperatures in these wells reflect the approach to regional temperature gradients away from the thermal anomaly (fig. 8).

Wells HF4 and HF5 are between The Narrows and the deep wells RRGE 1, 2, and 3, and figure 15 shows data for them along with data for H12. Wells HF4 and H12 have similar temperatures in their upper parts, though both have upward flows of water and lower temperature gradients in their deeper parts. Well HF5 is between these two wells and has lower temperatures and temperature gradients $\left(80,109^{\circ} \mathrm{C} / \mathrm{km}\right)$. The cooler behavior of HF 5 suggests a separation between the system found in the deep wells and the system found in The Narrows area.

Data for wells in the Upper Raft River Valley are given in figure 16. Almo 1 is an artesian well. Although temperatures in Almo 1 were measured through a packing gland, the high temperature at the surface indicates that the temperatures are probably still disturbed from previous episodes of flow. The maximum temperature in the well is $73.6^{\circ} \mathrm{C}$ at a depth of $484 \mathrm{ft}$, indicating the presence of flowing thermal water in the formation. The other wells are significantly cooler, with the warmest being H35 on one edge of the thermal anomaly in The Narrows. Almo 2, to the west of Almo 1, has a gradient of $50{ }^{\circ} \mathrm{C} / \mathrm{km}$, similar to regional values in other wells. Well $\mathrm{H} 21$ to the south has gradients of 52 and $89{ }^{\circ} \mathrm{C} / \mathrm{km}$ in its upper and lower parts, respectively, but its temperatures are not particularly high. Well H19 has a gradient of $53{ }^{\circ} \mathrm{C} / \mathrm{km}$ in its middle part, with a very low gradient below. The general behavior of the wells surrounding Almo 1 indicates that the thermal anomaly is relatively local but open towards the Jim Sage Mountains.

\section{Conclusions}

Combining data for the wells drilled as part of this study with those previously drilled allows better definition of the thermal anomalies in the Raft River area. A somewhat surprising finding is that many wells are affected by vertical water flows in the formation even when not within the active hydrothermal system. Obtaining quality temperature gradients in the sediments of the Raft River Valley was difficult, though it was possible to obtain reasonably representative temperature gradients in many wells. Some of the variations in temperature gradient are probably due to variations in thermal conductivities, but thermal conductivity data are lacking. 


\section{Acknowledgments}

The drill rig was contracted with Western Geophysical of Bakersfield, California, and the driller was Rod Lund, with helpers Greg Dean and Jerry Bainbridge. Mark Bond and Bennie Loebner provided field assistance during the drilling. Urban and Nathenson supervised the drilling and conducted the logging. Covington did the lithologic descriptions. Marianne Guffanti provided field assistance during the 1979 logging. Patrick Muffler and Steve Ingebritsen are thanked for helpful reviews.

\section{References Cited}

Ackermann, H.D., 1979, Seismic refraction study of the Raft River geothermal area, Idaho: Geophysics, v. 44, p. 216-225.

Bleim, C.J., Jr., 1983, The Raft River 5MW(e) binary geothermal-electric power plantOperation and performance: Geothermal Resources Council Transactions, v. 7, p. 3-13.

Bradford, J., McLennan, J., Moore, J., Glasby, D., Waters, D., Kruwell, R., Bailey, A., Rickard, W., Bloomfield, K., and King, D., 2013, Recent developments at the Raft River geothermal field: Proceedings Thirty-Eighth Workshop on Geothermal Reservoir Engineering, Stanford University, February 10-13, 2013, SGP-TR-198, 10 p., accessed May 17, 2013, at https://pangea.stanford.edu/ERE/pdf/IGAstandard/SGW/2013/2013program.html.

Bredehoeft, J.D., and Papadopulos, I.S., 1965, Rates of vertical groundwater movement estimated from the Earth's thermal profile: Water Resources Research, v. 1, p. 325-328.

Crosthwaite, E.G., 1976, Basic data from five core holes in the Raft River geothermal area, Cassia County, Idaho: U.S. Geological Survey Open-File Report 76-665, 12 p., 5 plates.

Dolenc, M.R., Hull, L.C., Mizell, S.A., Russell, B.F., Skiba, P.A., Strawn, J.A., and Tullis, J.A., 1981, Raft River geoscience case study: Idaho National Engineering Laboratory, EG\&G Idaho, Inc., EGG-2125, v. 1, 145 p., accessed May 17, 2013, at http://www.osti.gov/energycitations/ product.biblio.jsp?query_id=2\&page=0\&osti_id=6098820.

Keys, W.S., and Sullivan, J.K., 1979, Role of borehole geophysics in defining the physical characteristics of the Raft River geothermal reservoir, Idaho: Geophysics, v. 44, p. 1116-1141. Kunze, J.F., and Miller, L.G., 1974, Idaho geothermal R \& D project report for period December 16, 1973 to March 15, 1974: Aerojet Nuclear Company ANCR-1115, 38 p., accessed August 5, 2014, at http://www.osti.gov/geothermal/purl.cover.jsp?purl=/4279469-trYhrr/.

Mabey, D.R., Hoover, D.B., O'Donnell, J.E., and Wilson, C.W., 1978, Reconnaissance geophysical studies of the geothermal system in southern Raft River Valley, Idaho: Geophysics, v. 43, p. 1470-1484.

Nathenson, M., Urban, T.C., Diment, W.H., and Nehring, N.L., 1980, Temperatures, heat flow, and water chemistry from drill holes in the Raft River geothermal system, Cassia County, Idaho: U.S. Geological Survey Open-File Report 80-2001, 30 p.

Nathenson, M., Nehring, N.L., Crosthwaite, E.G., Harmon, R.S., Janik, C., and Borthwick, J., 1982, Chemical and light-stable isotope characteristics of waters from the Raft River geothermal area and environs, Cassia County, Idaho; Box Elder County, Utah: Geothermics, v. 11, p. 215-237.

Urban, T.C., Diment, W.H., Nathenson, M., Smith, E.P., Ziagos, J.P., and Shaeffer, M.H., 1986, Temperature, thermal-conductivity, and heat-flux data; Raft River area, Cassia County, Idaho (1974-1976): U.S. Geological Survey Open-File Report 86-123, 299 p. 
Urban, T.C., Diment, W.H., and Sorey, M.L., 1987, Temperatures and natural gamma-ray logs obtained in 1986 from Shady Rest drill hole RD08, Mammoth Lakes, Mono County,

California: U.S. Geological Survey Open-File Report 87-291, 100 p.

Williams, P.L., Covington, H.R., and Pierce, K.L., 1982, Cenozoic stratigraphy and tectonic evolution of the Raft River basin, Idaho, in Bonnichsen, B., and Breckenridge, R.M., eds., Cenozoic geology of Idaho: Idaho Bureau of Mines and Geology Bulletin 26, p. 491-504.

Williams, P.L., Mabey, D.R., Zohdy, A.A.R., Ackerman, H., Hoover, D.B., Pierce, K.L., and Oriel, S.S., 1976, Geology and geophysics of the southern Raft River Valley geothermal area, Idaho, U.S.A.: Proceedings, Second United Nations Symposium on the Development and Use of Geothermal Resources, San Francisco, Calif., 1975, v. 2, p. 1273-1282.

Ziagos, J.P., and Blackwell, D.D., 1986, A model for the transient temperature effects of horizontal fluid flow in geothermal systems: Journal of Volcanology and Geothermal Research, v. 27, p. 371-397.

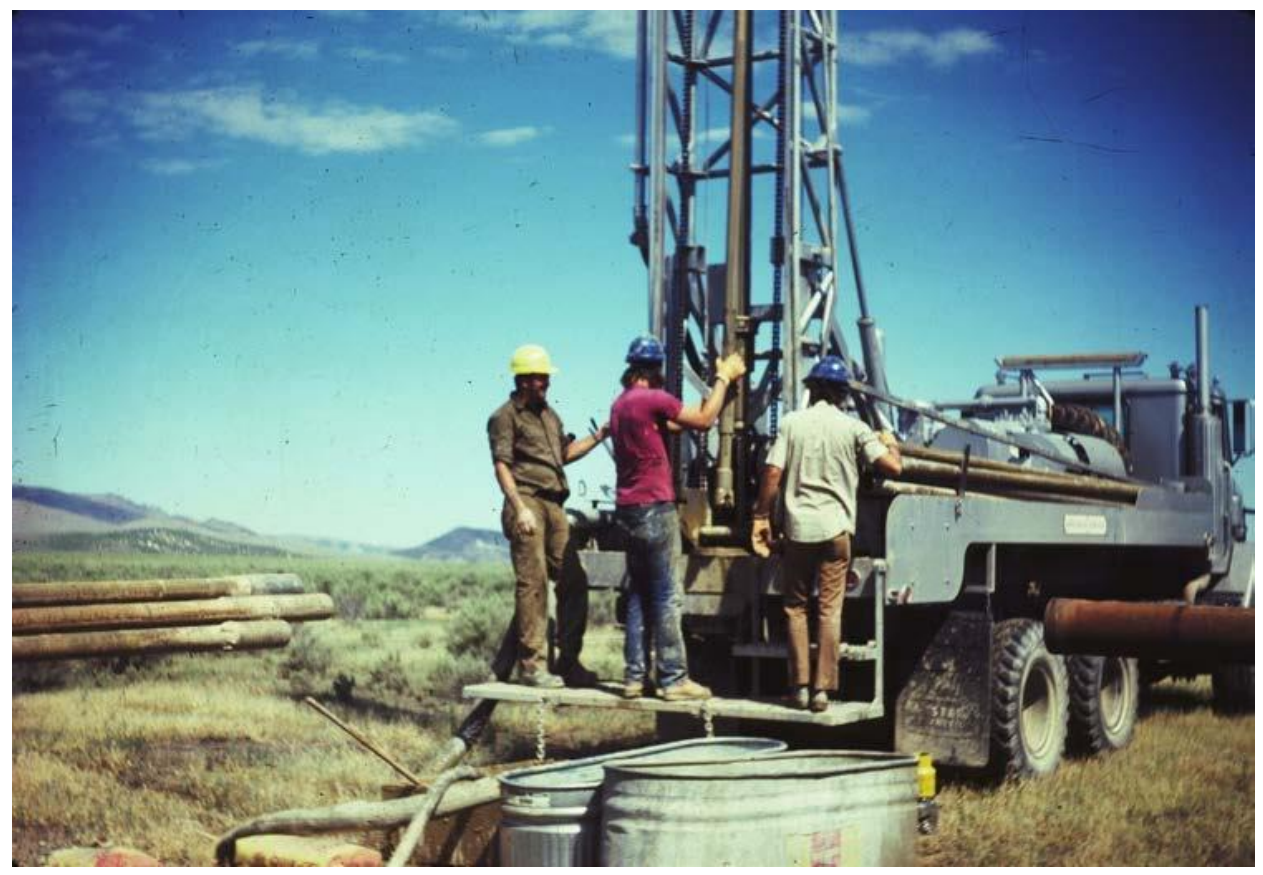

Figure 1. Photograph of drilling rig on well H01 with 4 1⁄2-inch diameter drill bit (August 21, 1977). 


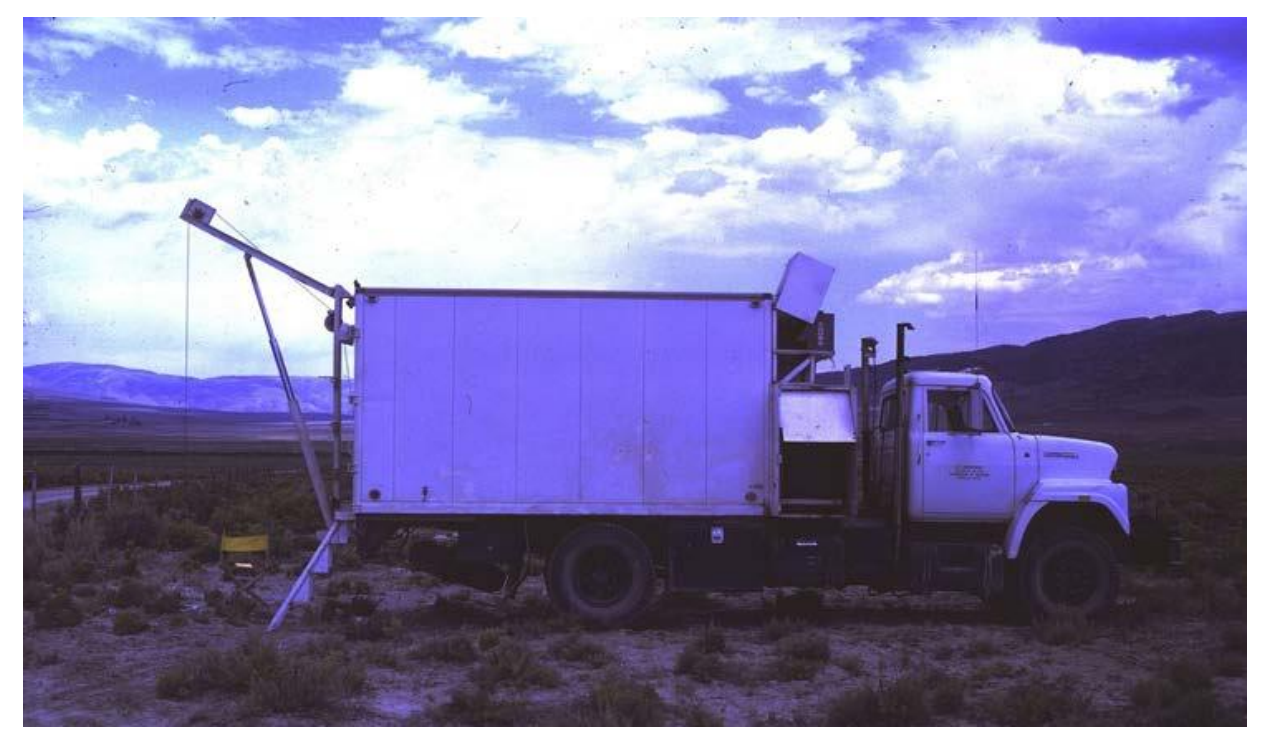

Figure 2. Photograph of logging truck with cable in well (1979).

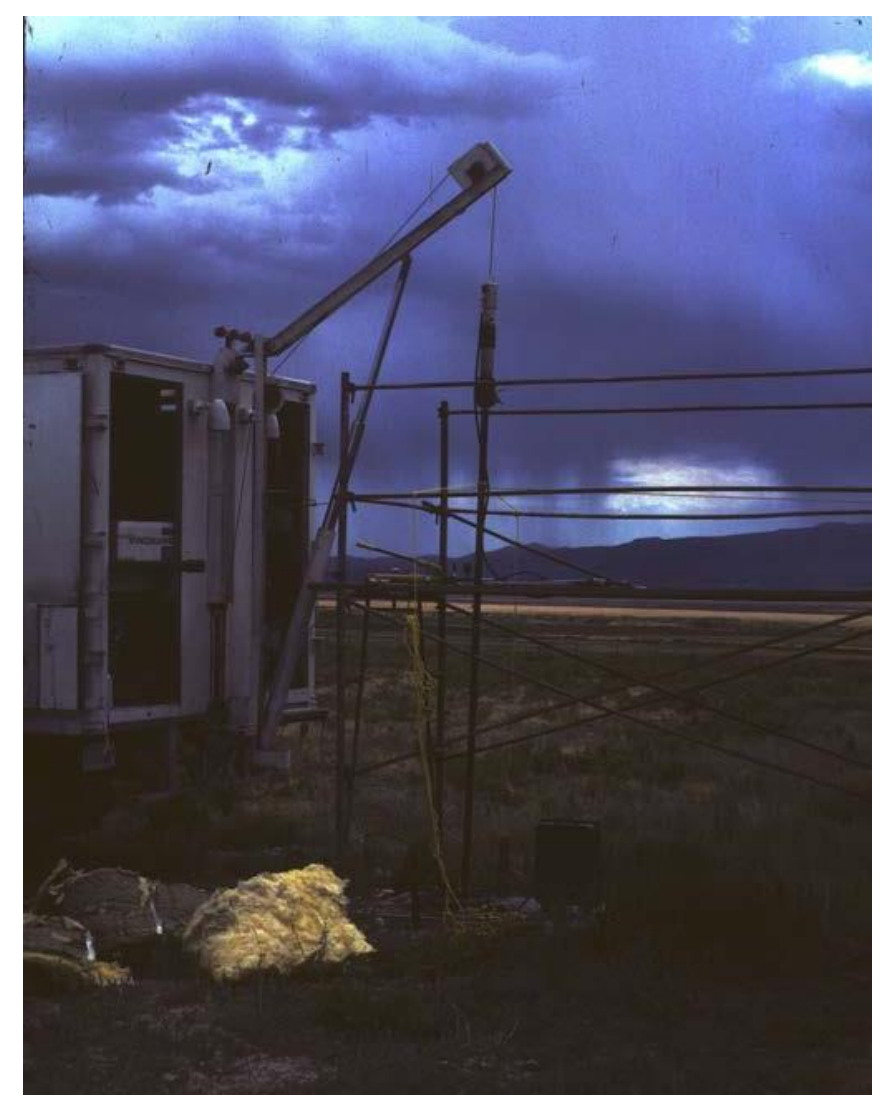

Figure 3. Photograph showing logging of well I.D.3 with stand pipe and packing gland on top (August 11, 1976). 


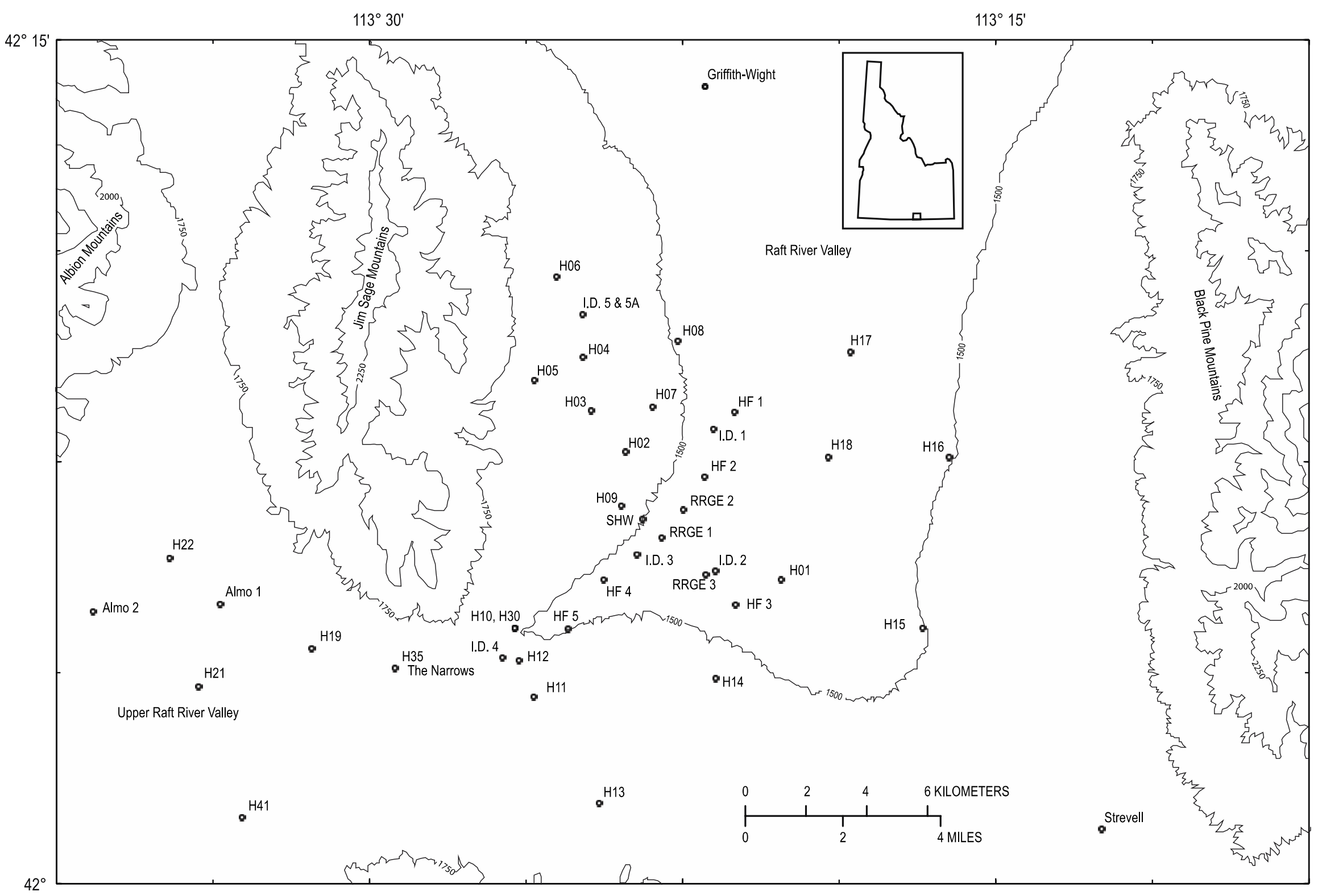

Figure 4. Map showing locations for drill holes reported in this study, Raft River Valley, Idaho. Elevation contours in meters. Inset shows map of Idaho with an outline of the area shown in the figure. 


\begin{tabular}{|c|c|c|c|}
\hline$b$ & a & b & a \\
\hline C & $d$ & C & $d$ \\
\hline b & a & b & a \\
\hline C & $d$ & C & $d$ \\
\hline
\end{tabular}

Figure 5. Diagram of letter codes designating parts of sections for the location data given in table 1. 


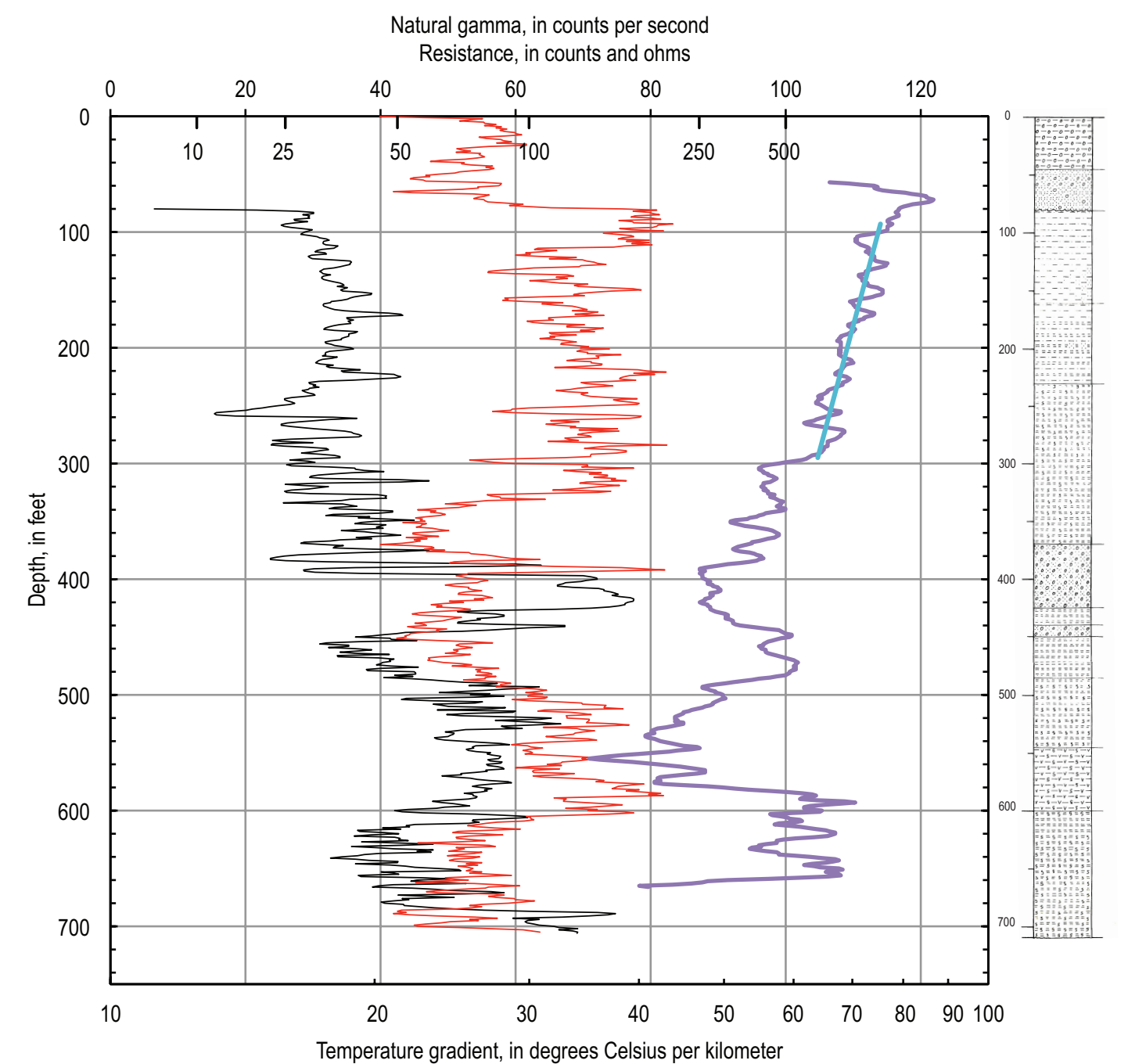

$\begin{array}{ll} & \text { FAN ALLUVIUM } \\ 0-45 \mathrm{ft} & \text { Gravel in a tan, calcareous silt matrix. Gravel: subrounded clasts of gray }\end{array}$ and black rhyolite lava as much as $3 \mathrm{~cm}$ in diameter

45-80 f t Sand and gravel in a tan silt matrix. Sand: coarse, angular grains of red and gray rhyolite lava. Gravel: subangular clasts of red and gray rhyolite lava as much as $2 \mathrm{~cm}$ in diameter

SALT LAKE FORMATION

80-160 ft Siltstone: salmon-colored, calcareous; sandy below $130 \mathrm{ft}$, with medium sand grains of gray rhyolite lava and green secondary silica

160-230 ft Claystone and siltstone in alternating laminae; salmon-colored, very hard

230-370 ft Claystone: alternating light green and salmon-colored laminae, very hard; appears partly silicified in places. Below $310 \mathrm{ft}$ light green laminae change to dark gray and become slightly calcareous

$370-425 \mathrm{ft} \quad$ Conglomerate: subangular to subrounded clasts of quartz monzonite and minor quartzite as much as $10 \mathrm{~cm}$ in diameter in a clean quartz sand matrix. Sand: subangular to rounded and fine to medium grained

425-440 ft Claystone: light and dark gray laminae, micaceous, calcareous

$440-450 \mathrm{ft}$ Conglomerate: subangular to subrounded clasts of quartz monzonite and minor quartzite as much as $10 \mathrm{~cm}$ in diameter in a clean quartz sand matrix

450-485 ft Claystone: light and dark gray laminae, micaceous, calcareous

$485-545 \mathrm{ft}$ Claystone: alternating beds of light gray, micaceous and calcareous claystone and dark gray silicified claystone

$545-600 \mathrm{ft} \quad$ Siltstone: light green, tuffaceous, partly silicified

600-709 ft Claystone: alternating beds and laminae of light gray calcareous claystone and dark gray silicified claystone. Dark gray silicified claystone is brecciated in places and is within the light-gray claystone

Figure 6. Lithologic columnar section and geophysical logs for well H04. Natural gamma-ray (in counts per second) and

EXPLANATION

- Resistance 10/2/77

Natural gamma 10/3/77 resistance (in counts) shown on the same top scale with resistance values (in ohms) shown on the scale within the plot area.

Gradient Temperature gradient data are shown with the bottom $(\mathrm{log})$ scale and are calculated over 10 -foot intervals with the value plotted near the mid-point of the interval. Straight-line match to the natural log of the temperature gradient is shown. See figure A-1 for lithology symbol key. For Salt Lake Formation see Williams and others (1982). 


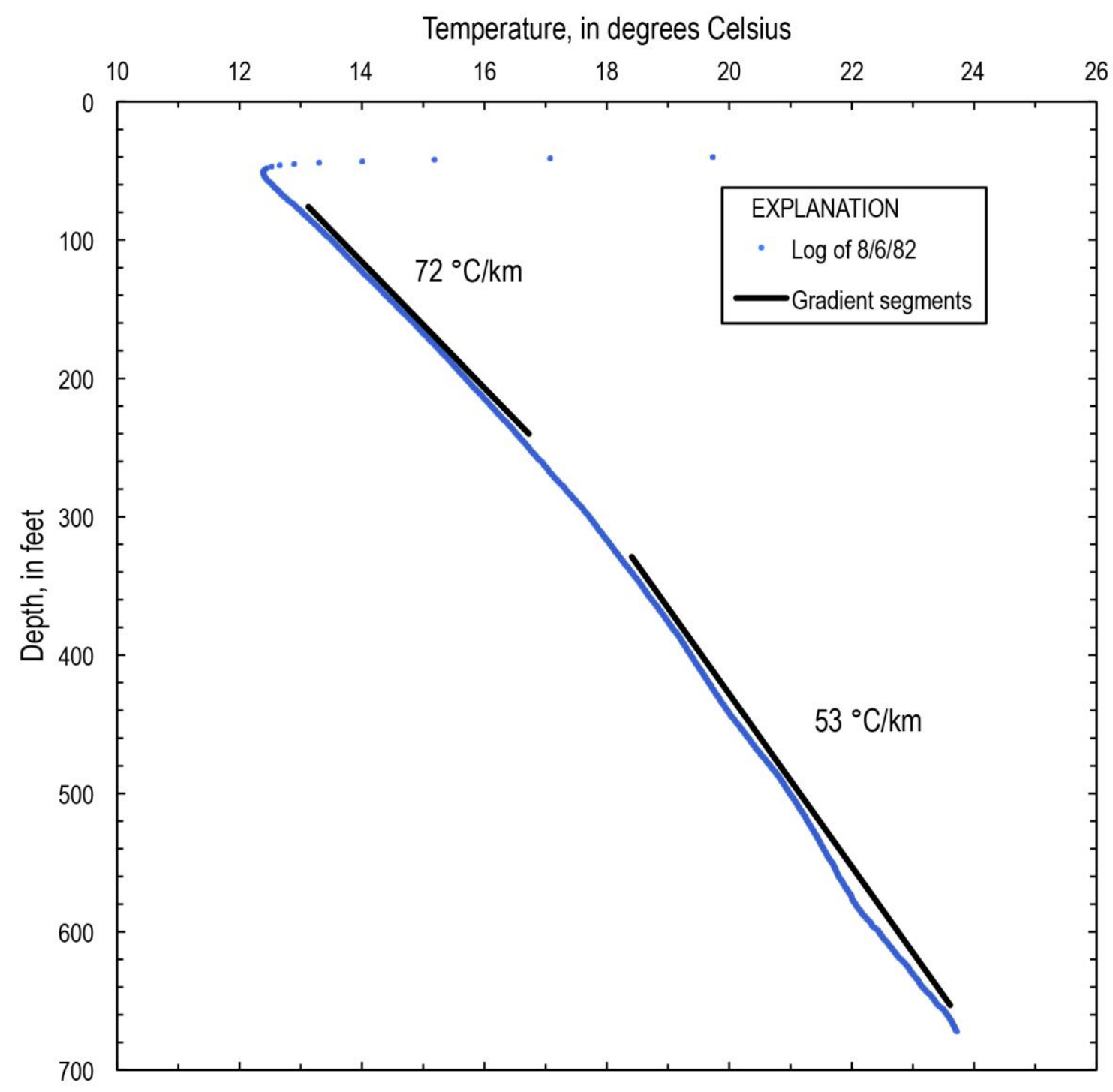

Figure 7. Graph of temperature versus depth for well H04. Straight lines for calculating temperature gradients are shown over intervals chosen by eye, and the lines are displaced from the data by $0.2^{\circ} \mathrm{C}$ for clarity. 


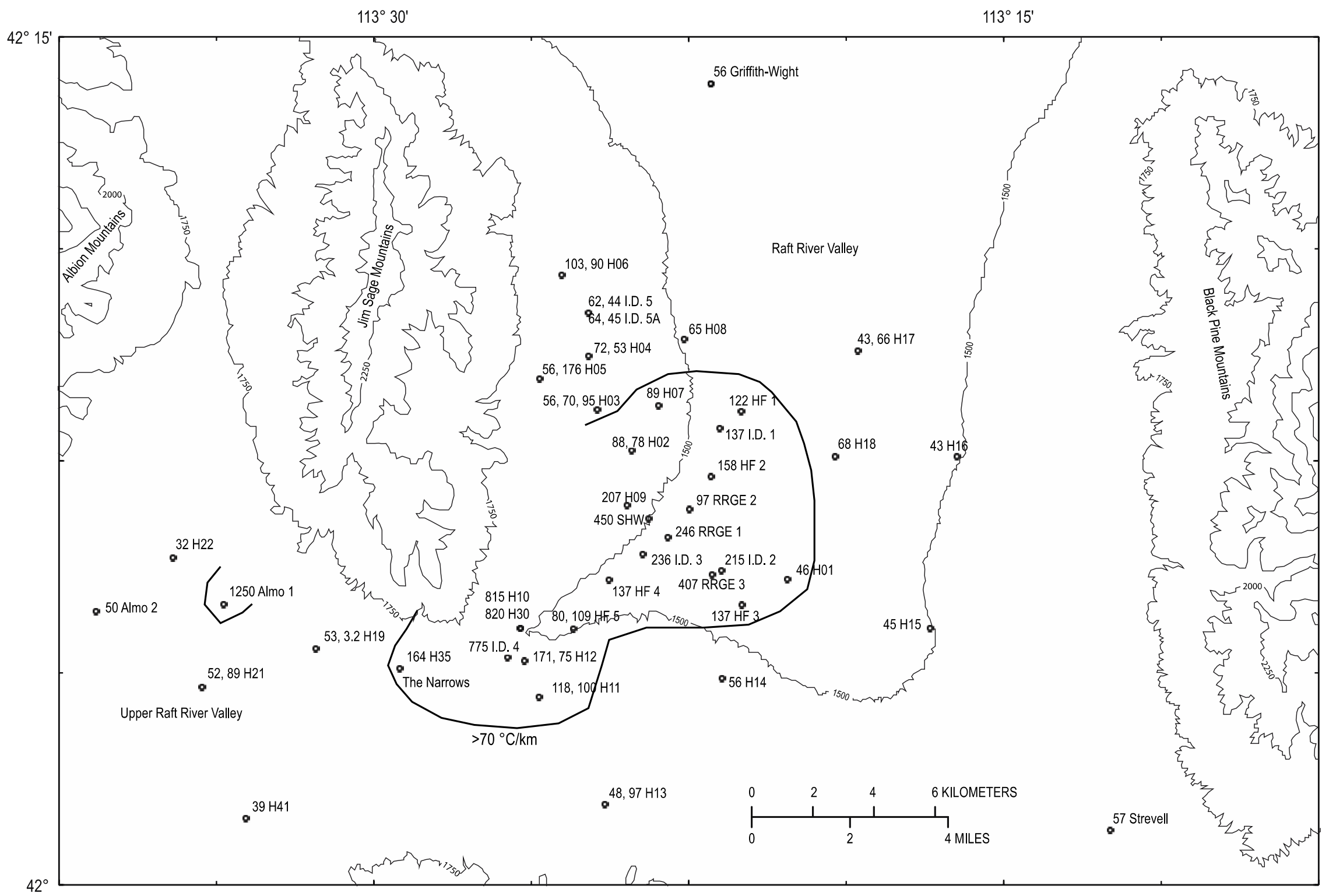

Figure 8. Map of locations of drill holes along with representative temperature gradients (in ${ }^{\circ} \mathrm{C} / \mathrm{km}$ ) listed before well name (for some wells, two gradients are for different depth intervals), Raft River Valley, Idaho. Outline of identified geothermal anomalies with temperature gradient $>70{ }^{\circ} \mathrm{C} / \mathrm{km}$ shown. Elevation contours in meters. 


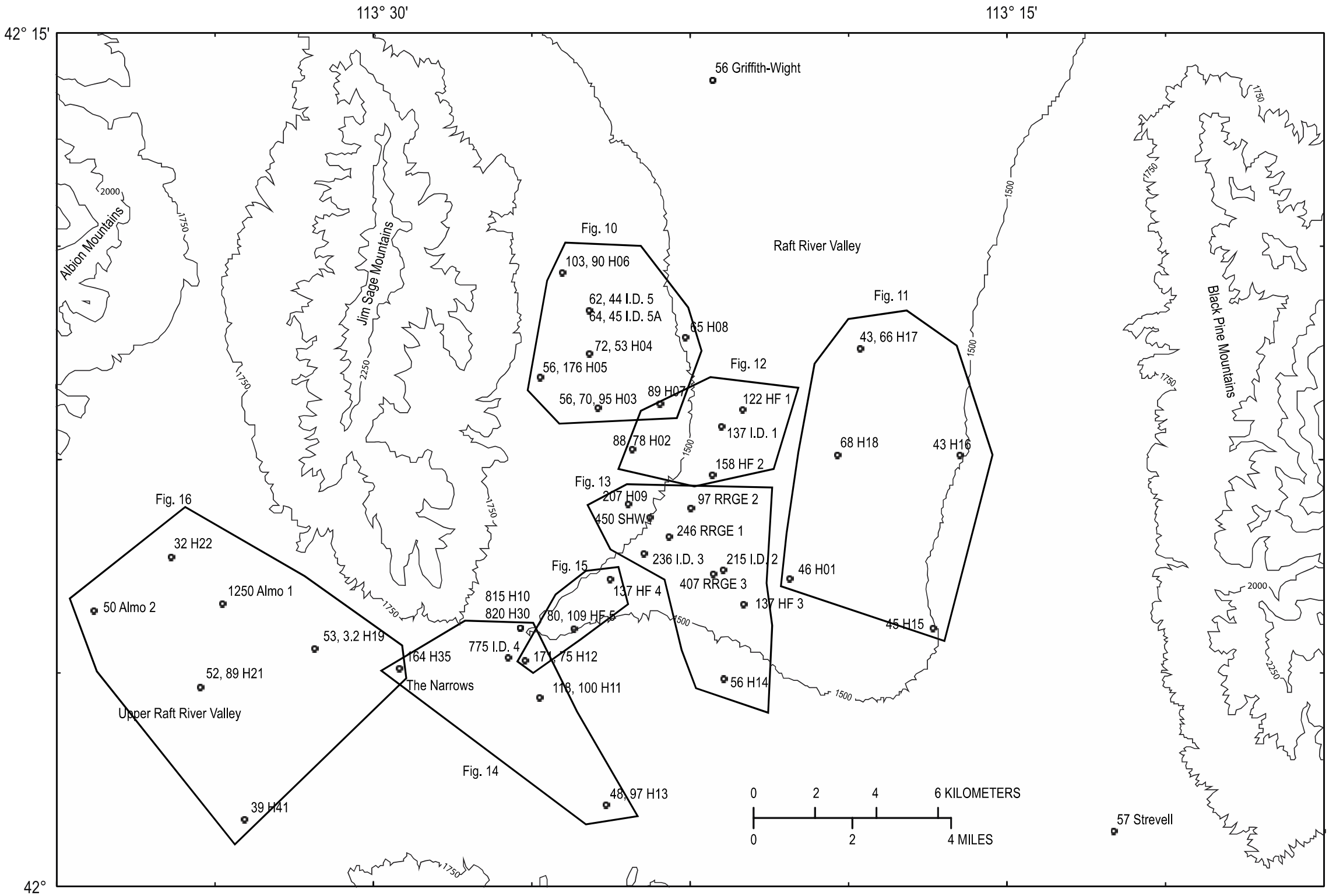

Figure 9. Map of locations of drill holes in Raft River Valley, Idaho, showing areas for plots of temperature versus depth (figs. 10-16) along with representative temperature gradients (for some wells, two gradients are for different depth intervals). Where areas overlap, data for that drill hole are shown on both plots. Elevation contours in meters. 


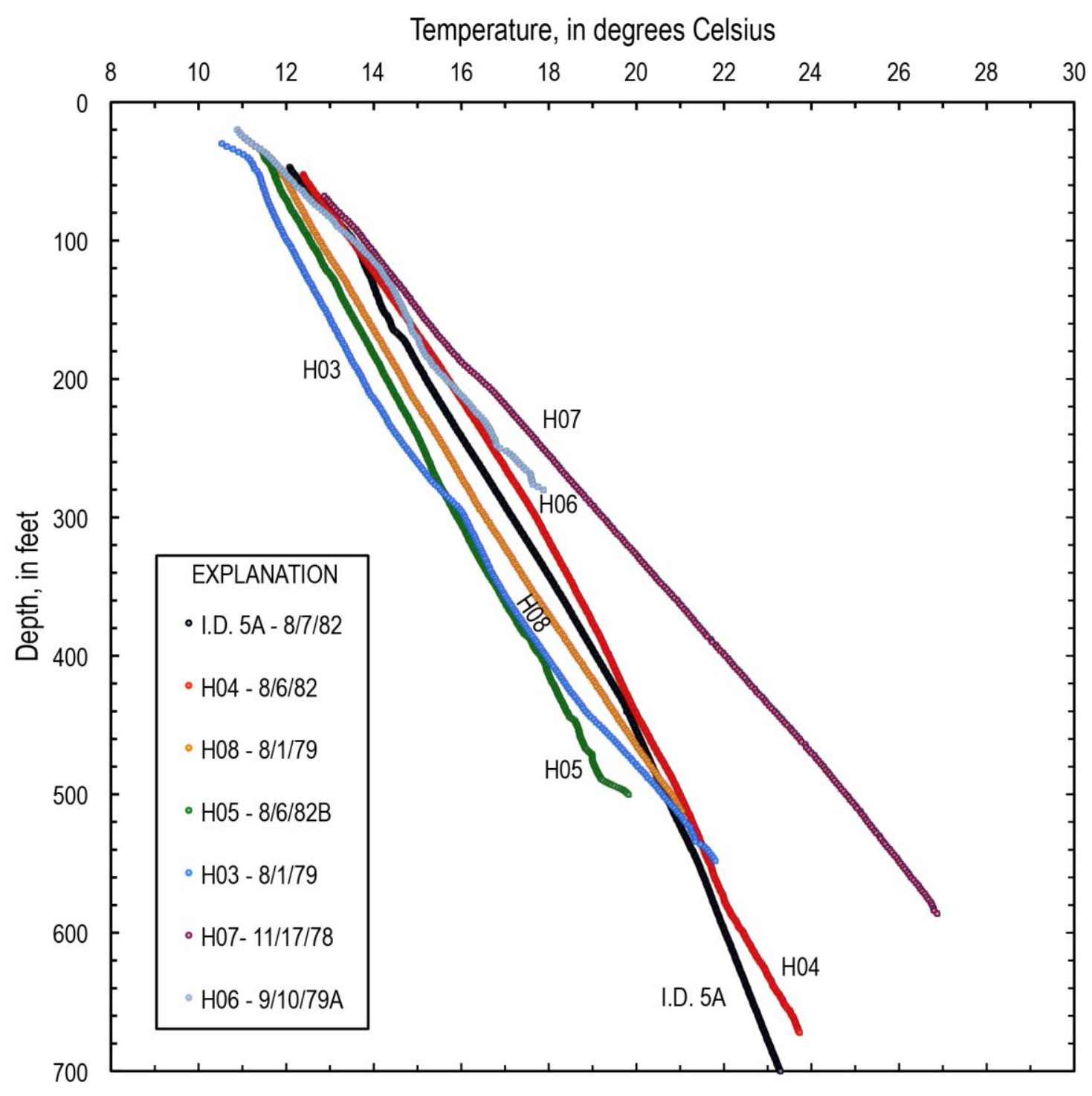

Figure 10. Graph of temperature versus depth for drill holes in the northwest part of the Raft River Valley. Dates of logging in $\mathrm{m} / \mathrm{d} / \mathrm{yy}$ format. 


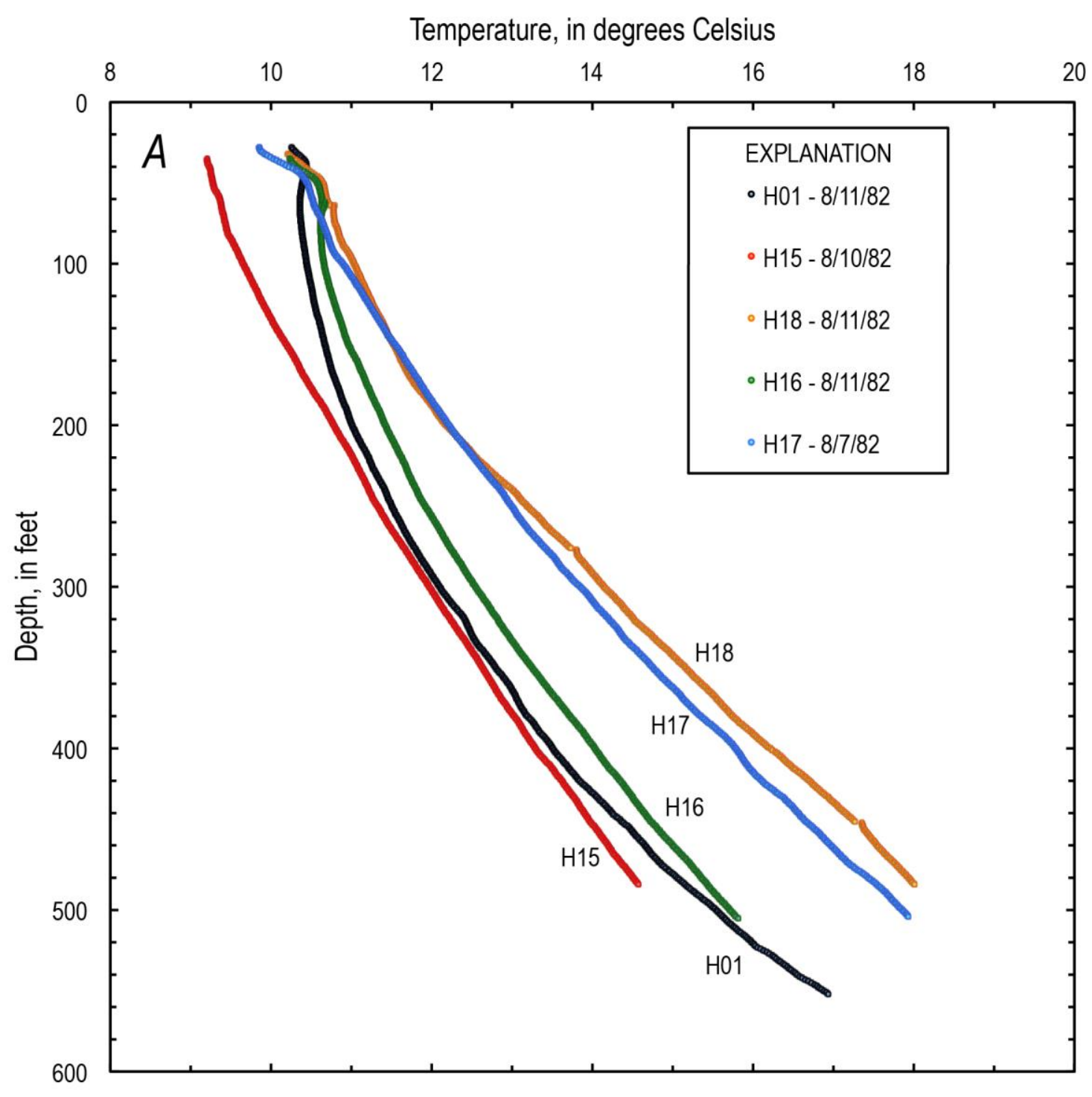

Figure 11. Data for drill holes in the eastern part of the Raft River Valley. Dates of logging in $\mathrm{m} / \mathrm{d} / \mathrm{yy}$ format. $A$, Graph of temperature versus depth. $B$, Graph of temperature versus depth and temperature gradients (note log scale) for drill holes $\mathrm{H} 01$ and $\mathrm{H} 16$. Temperature gradient data are shown with the bottom (log) scale and are calculated over 10-foot intervals with the value plotted near the mid-point of the interval. Straight-line matches to the natural log of the temperature gradient are shown for model for vertical flow of water. 


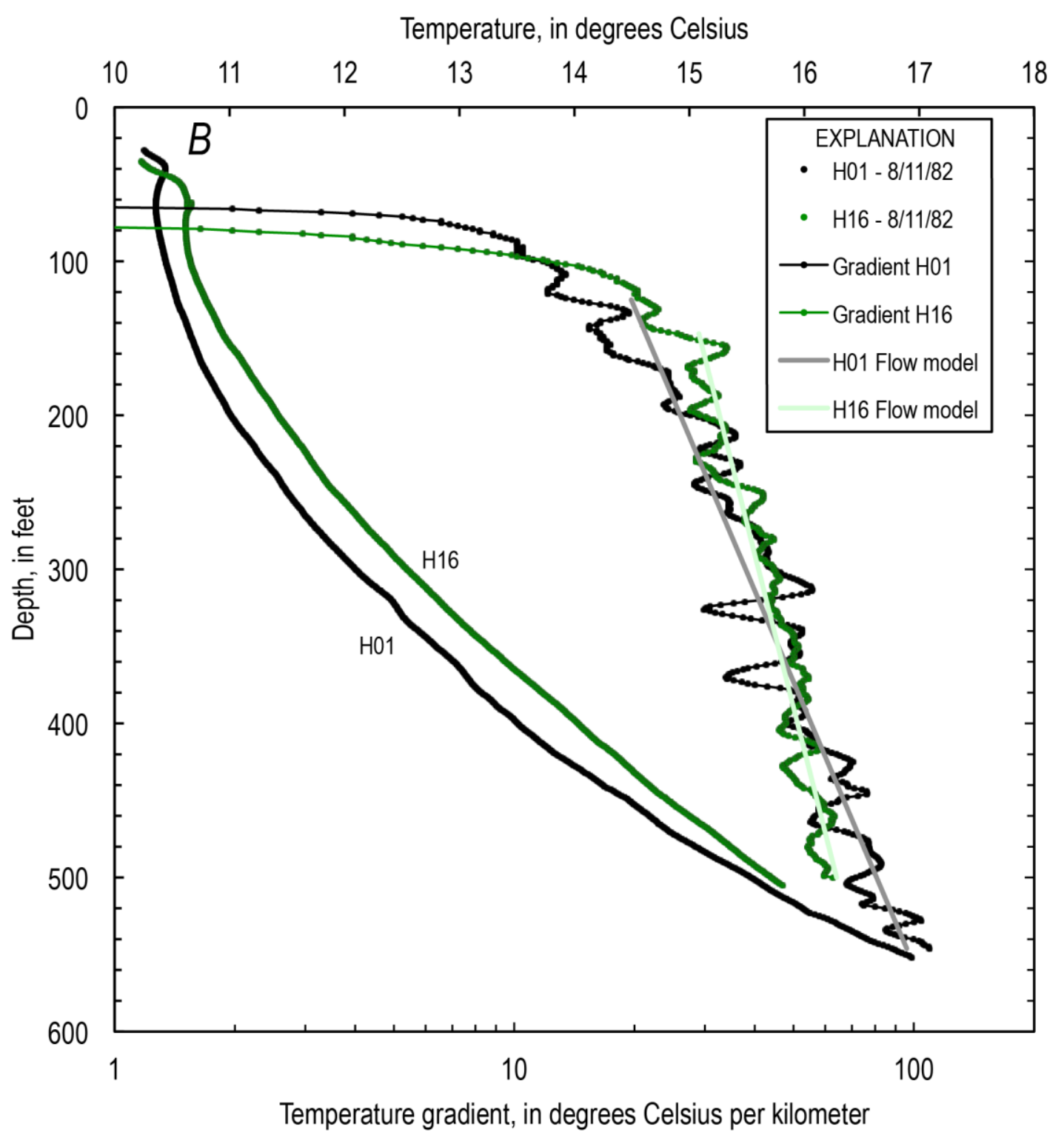

Figure 11.-Continued 


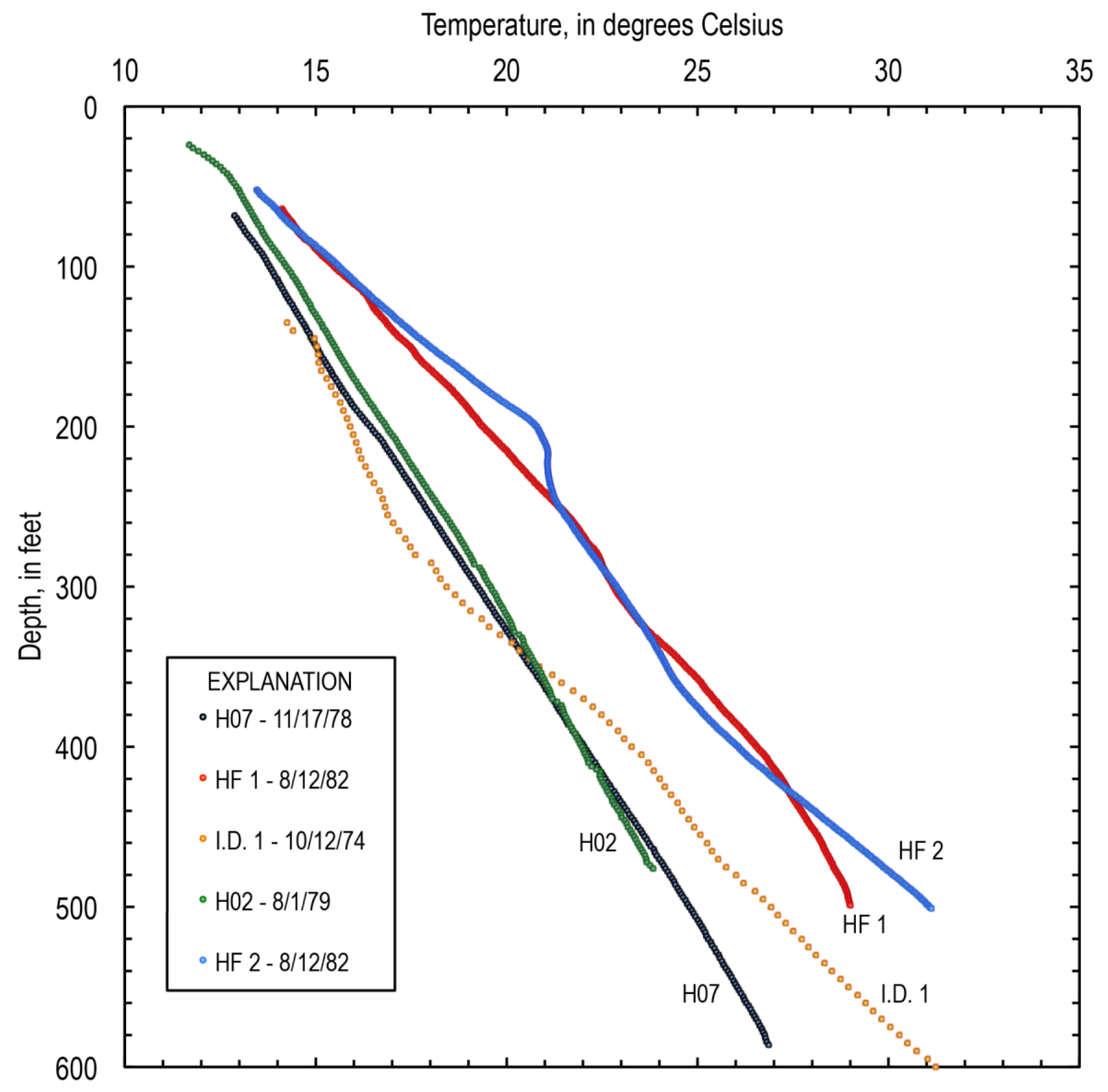

Figure 12. Graph of temperature versus depth for drill holes north of the deep well area, Raft River Valley. Dates of logging in $\mathrm{m} / \mathrm{d} / \mathrm{yy}$ format. 


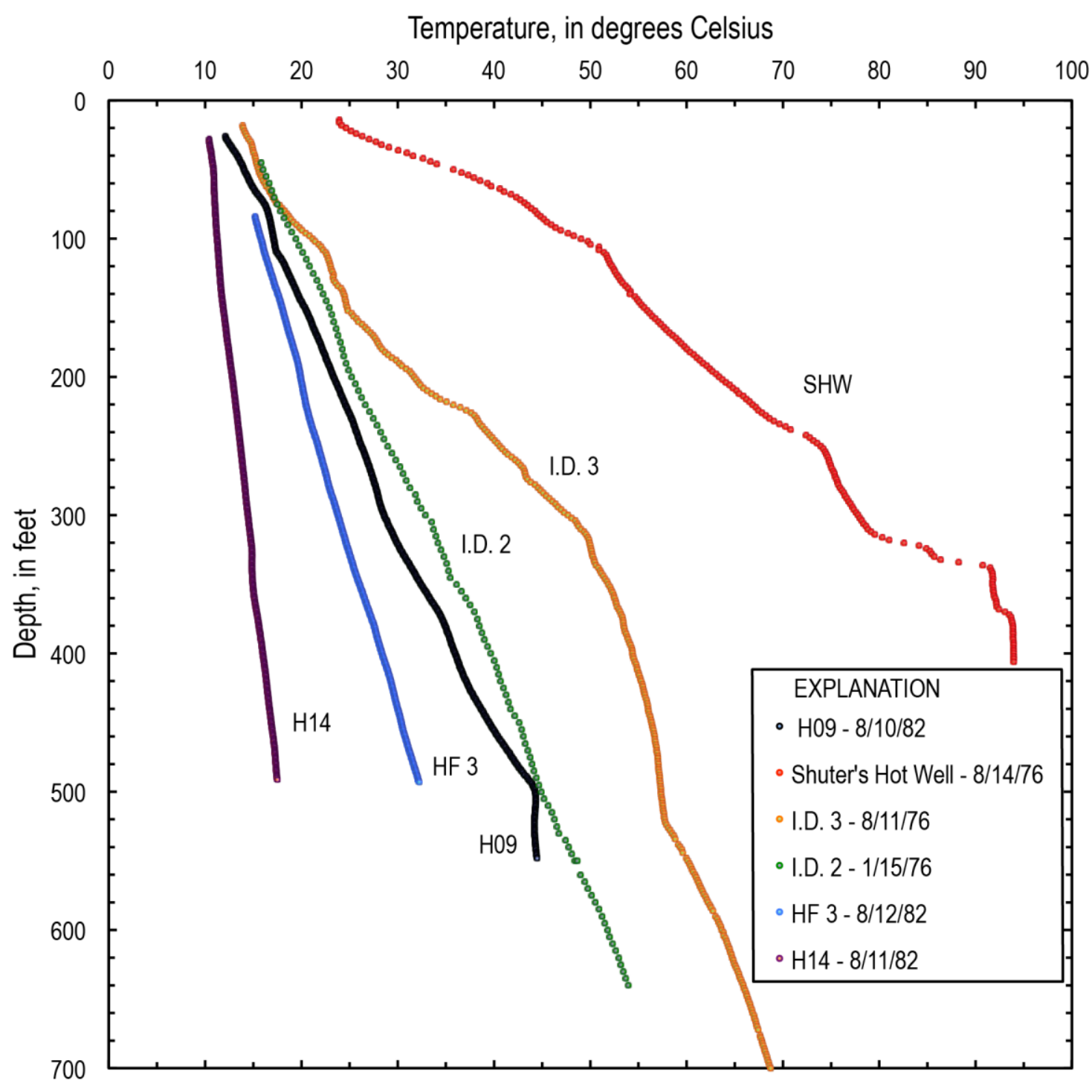

Figure 13. Graph of temperature versus depth for drill holes in the deep well area, Raft River Valley. Dates of logging in $\mathrm{m} / \mathrm{d} / \mathrm{yy}$ format. 


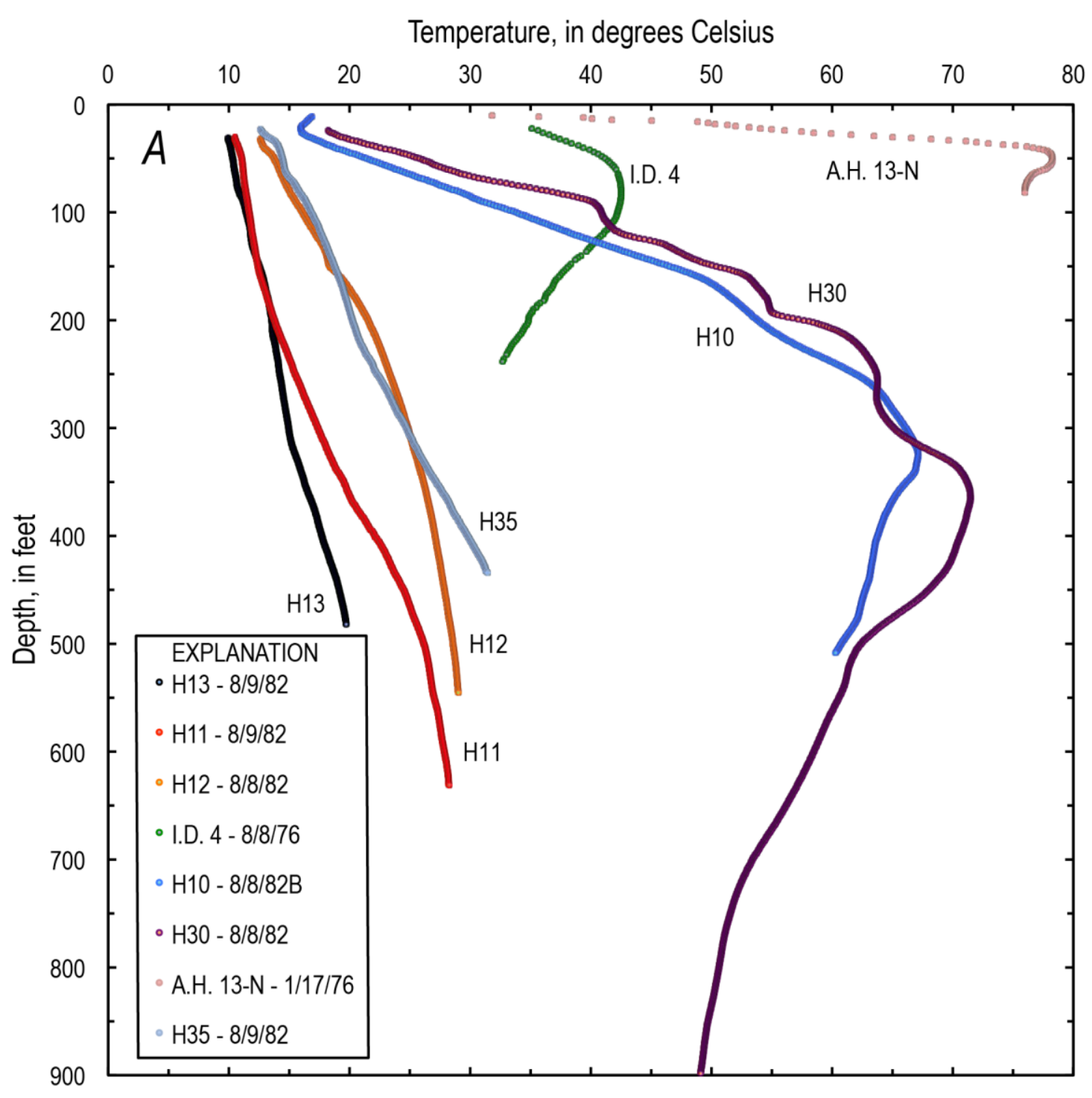

Figure 14. Data for wells in the Narrows area, Raft River Valley. Dates of logging in $\mathrm{m} / \mathrm{d} / \mathrm{yy}$ format. $A$, Graph of temperature versus depth. $B$, Graph of temperature versus depth with expanded scales and temperature gradient for selected drill holes in The Narrows area. Temperature gradient data are shown with the bottom (log) scale and are calculated over 10-foot intervals with the value plotted near the mid-point of the interval. Straight-line matches to the natural log of the temperature gradient are shown for model for vertical flow of water. 


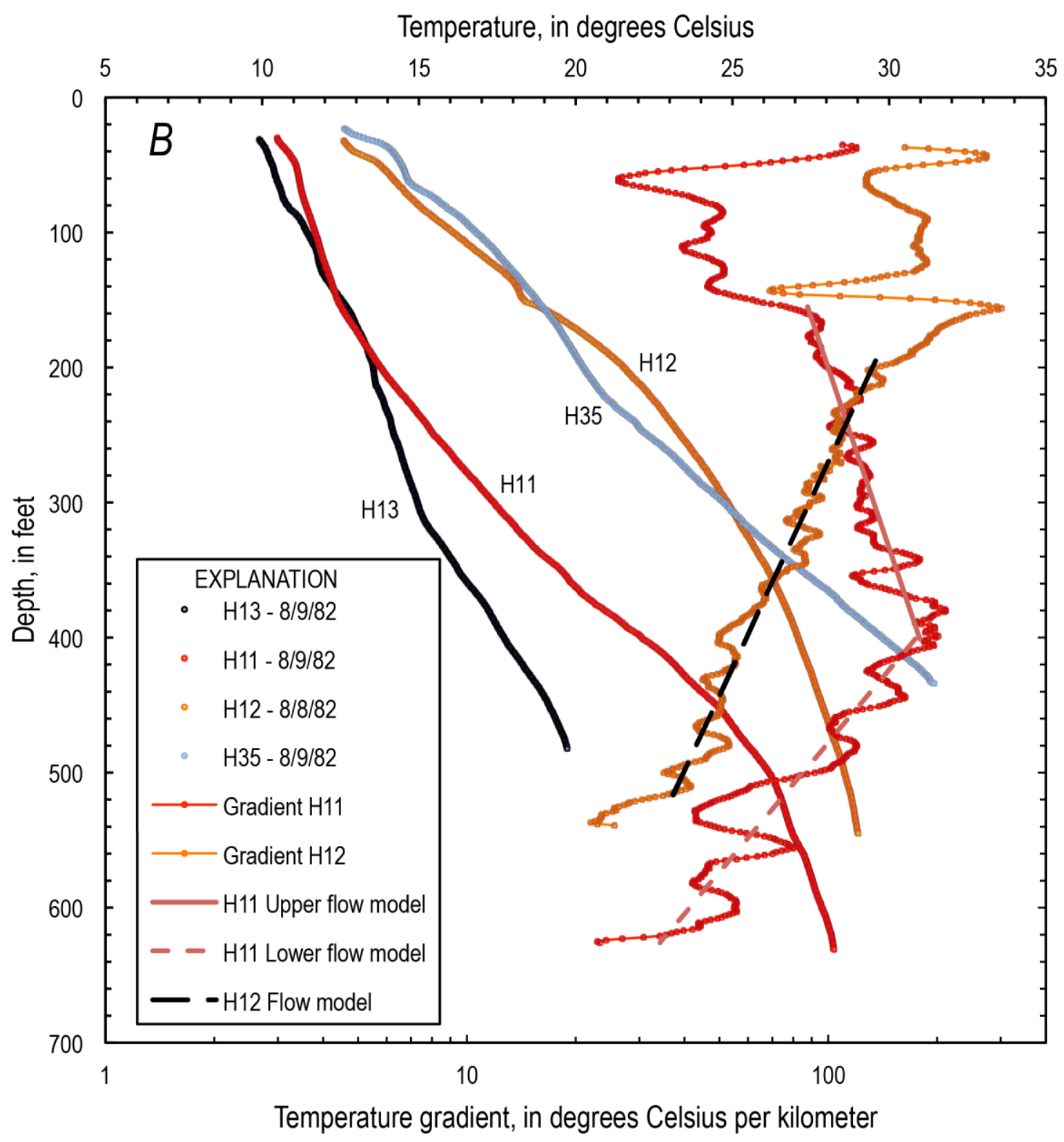

Figure 14.-Continued 


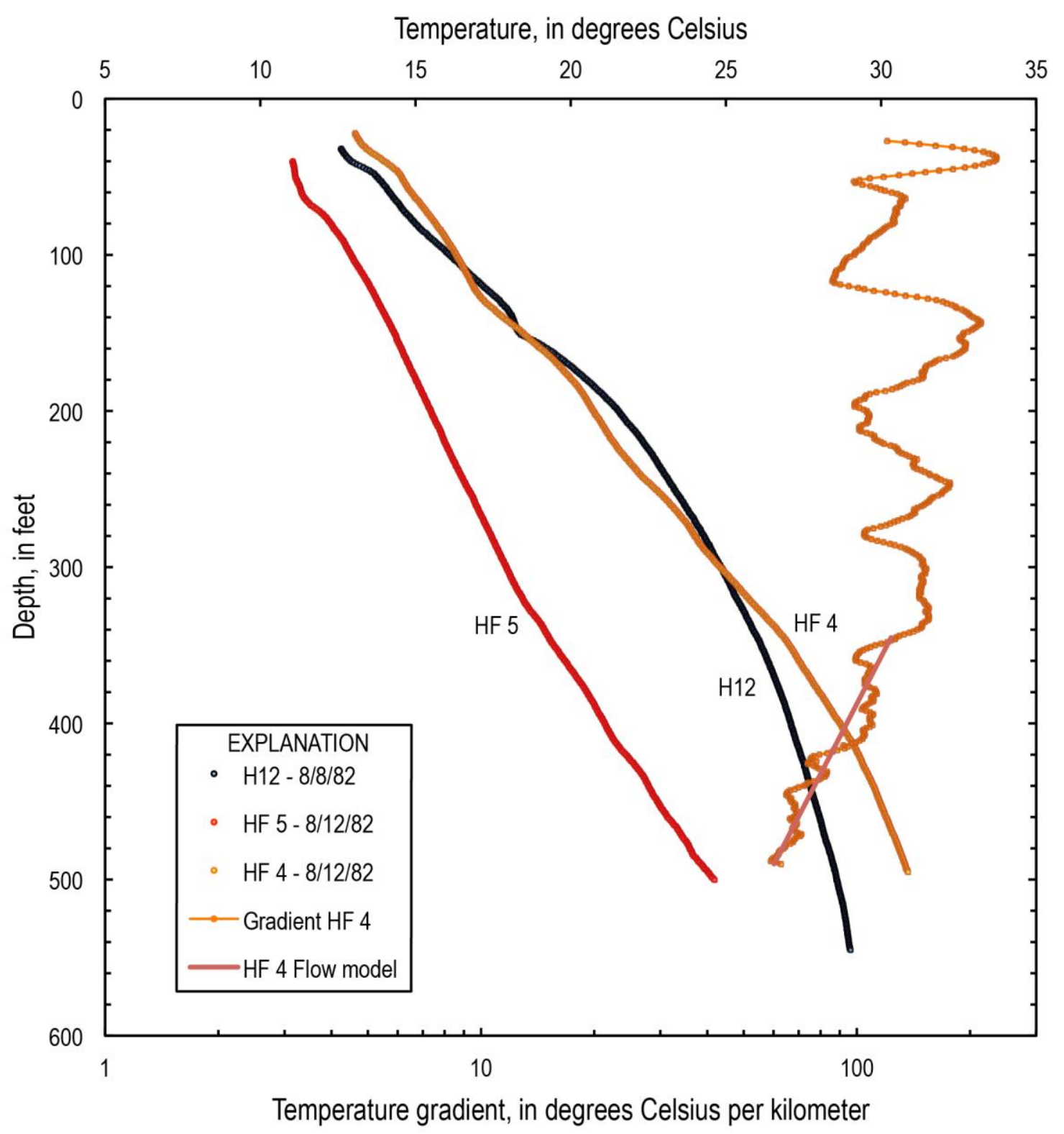

Figure 15. Graph of temperature versus depth and temperature gradient for drill holes between The Narrows and deep well areas. Temperature gradient data are shown with the bottom (log) scale and are calculated over 10-foot intervals with the value plotted near the mid-point of the interval. Straight-line match to the natural log of the temperature gradient is shown for model for vertical flow of water. Dates of logging in $\mathrm{m} / \mathrm{d} / \mathrm{y} y$ format. 


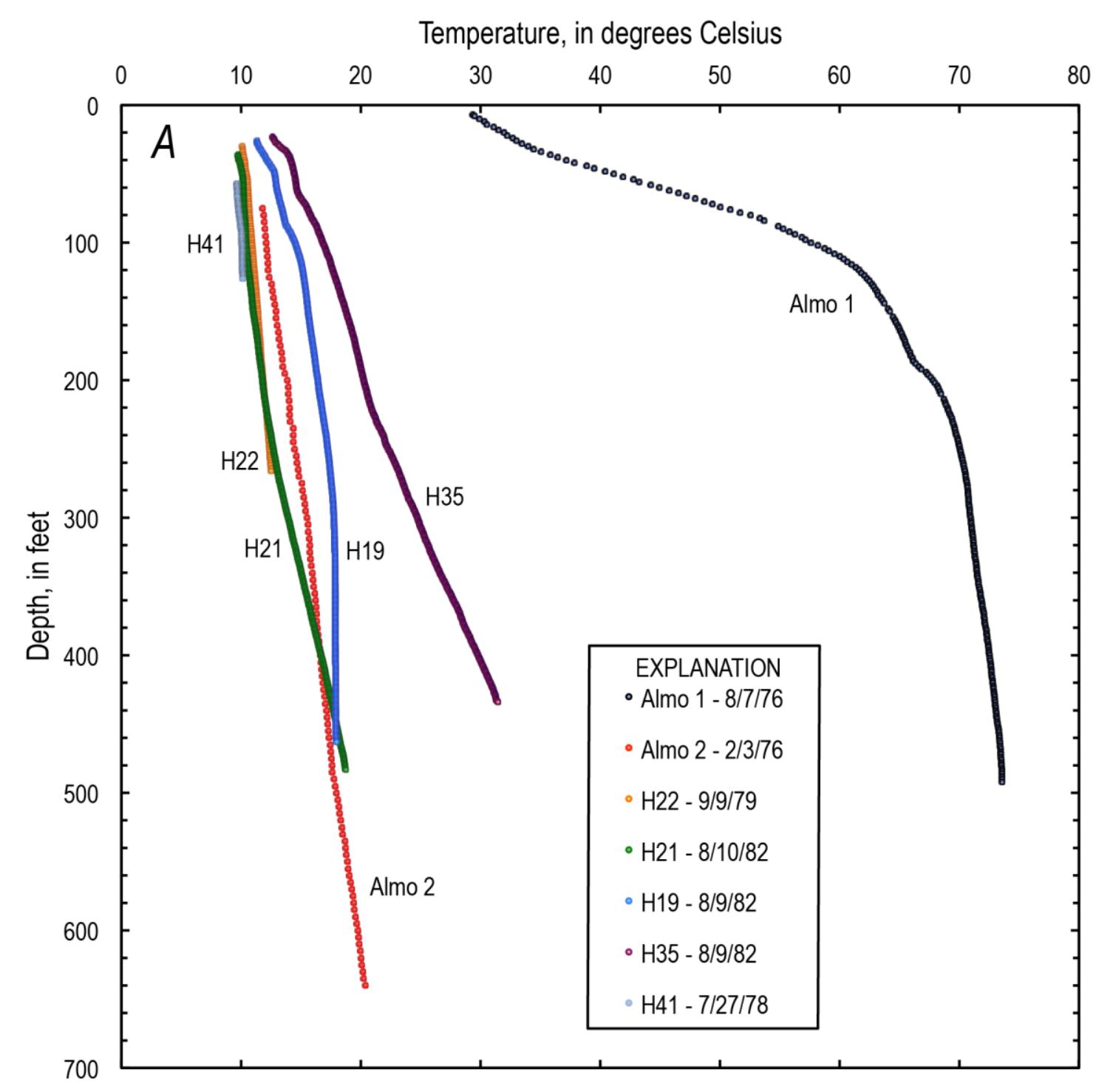

Figure 16. Data for wells in the Upper Raft River Valley. Dates of logging in $\mathrm{m} / \mathrm{d} / \mathrm{yy}$ format. $A$, Graph of temperature versus depth for drill holes. $B$, Graph of temperature versus depth for drill holes in the Upper Raft River Valley on an expanded scale, without data for Almo 1. 


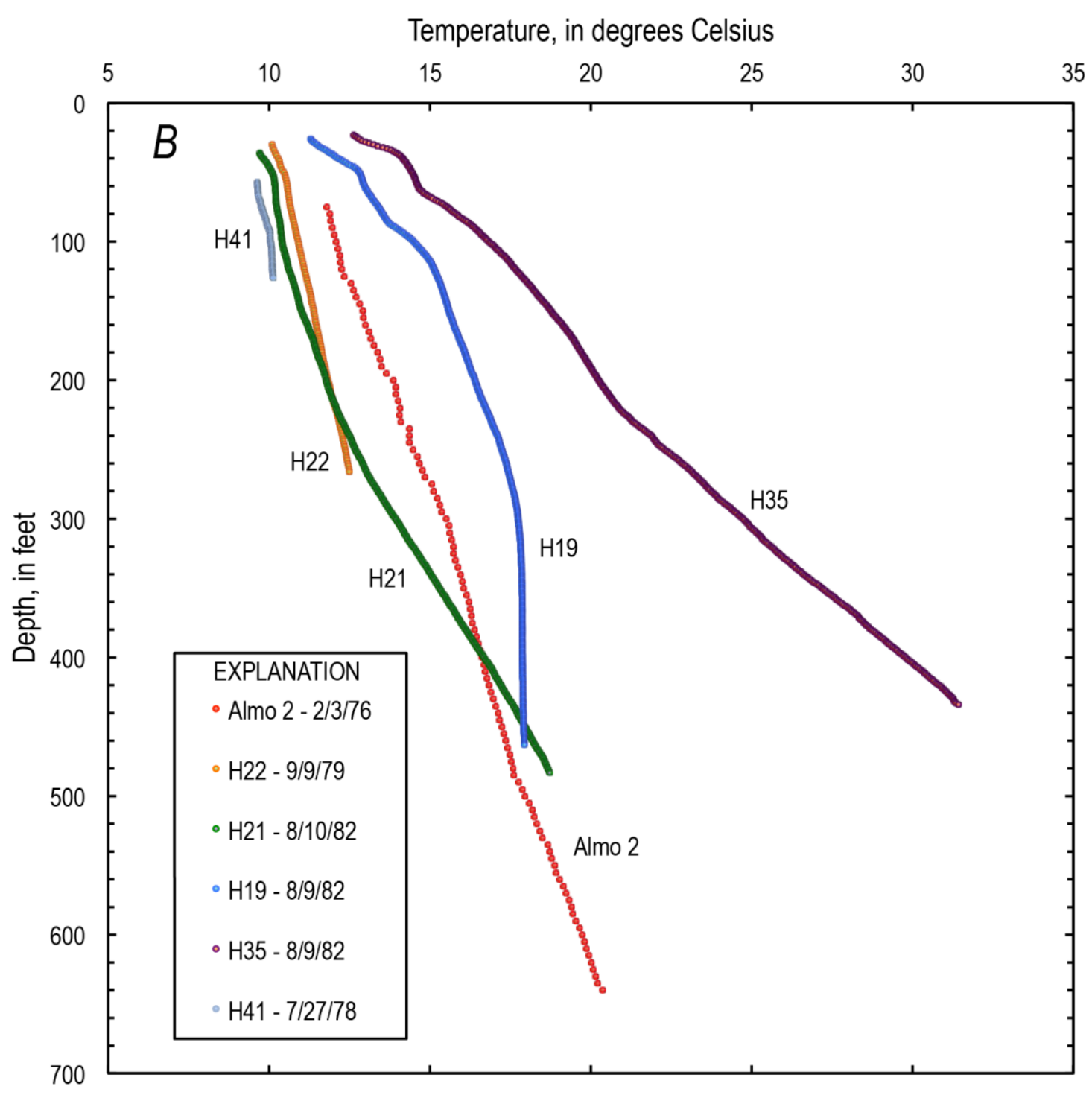

Figure 16.-Continued 
Table 1. Locations of drill holes reported in this study.

[Drilled dates ( $\mathrm{m} / \mathrm{d} / \mathrm{yy}$ format) and cased depths given for wells drilled as part of this study; TD, total depth. T.R.S. is Township, Range, and Section as given on USGS topographic maps. Letter codes for parts of sections explained in figure 5. Locations use North American Datum of 1927]

\begin{tabular}{|c|c|c|c|c|c|c|}
\hline Name & T. R. S. & Latitude & Longitude & $\begin{array}{c}\text { Elevation } \\
\text { (ft) }\end{array}$ & Drilled dates & $\begin{array}{l}\text { Cased depth } \\
\text { (ft) }\end{array}$ \\
\hline Griffith-Wight & 14S-26E-1bdb & $42^{\circ} 14.17^{\prime}$ & $113^{\circ} 21.97^{\prime}$ & 4,630 & & \\
\hline H06 & $14 \mathrm{~S}-26 \mathrm{E}-28 \mathrm{bac}$ & $42^{\circ} 10.79^{\prime}$ & $113^{\circ} 25.53^{\prime}$ & 5,435 & $9 / 14 / 77$ & 80 (320 TD) \\
\hline I.D. $5 \mathrm{~A}$ & 14S-26E-33aab & $42^{\circ} 10.12^{\prime}$ & $113^{\circ} 24.90^{\prime}$ & 5,240 & & \\
\hline H04 & $14 \mathrm{~S}-26 \mathrm{E}-33 \mathrm{ddc}$ & $42^{\circ} 09.36^{\prime}$ & $113^{\circ} 24.89^{\prime}$ & 5,260 & $9 / 6 / 77-10 / 3 / 77$ & 705 \\
\hline H08 & $14 \mathrm{~S}-26 \mathrm{E}-35 \mathrm{dab}$ & $42^{\circ} 09.65^{\prime}$ & $113^{\circ} 22.62^{\prime}$ & 4,900 & $9 / 16 / 77-9 / 20 / 77$ & 515 \\
\hline H17 & $14 \mathrm{~S}-27 \mathrm{E}-33 \mathrm{cdb}$ & $42^{\circ} 09.45^{\prime}$ & $113^{\circ} 18.48^{\prime}$ & 4,700 & $12 / 5 / 77-12 / 17 / 77$ & 504 \\
\hline Almo 2 & $15 \mathrm{~S}-24 \mathrm{E}-35 \mathrm{aab}$ & $42^{\circ} 04.84^{\prime}$ & $113^{\circ} 36.62^{\prime}$ & 5,240 & & \\
\hline Almo 1 & $15 \mathrm{~S}-25 \mathrm{E}-29 \mathrm{cdd}$ & $42^{\circ} 04.97^{\prime}$ & $113^{\circ} 33.58^{\prime}$ & 5,140 & & \\
\hline $\mathrm{H} 22$ & $15 \mathrm{~S}-25 \mathrm{E}-30 \mathrm{baa}$ & $42^{\circ} 05.79^{\prime}$ & $113^{\circ} 34.79^{\prime}$ & 5,180 & $1 / 7 / 78-1 / 9 / 78$ & 268 \\
\hline H19 & $15 \mathrm{~S}-25 \mathrm{E}-34 \mathrm{cdb}$ & $42^{\circ} 04.18^{\prime}$ & $113^{\circ} 31.39^{\prime}$ & 5,080 & $12 / 20 / 77-1 / 7 / 78$ & 463 \\
\hline H07 & $15 \mathrm{~S}-26 \mathrm{E}-2 \mathrm{cdc}$ & $42^{\circ} 08.48^{\prime}$ & $113^{\circ} 23.22^{\prime}$ & 5,020 & $9 / 15 / 77-9 / 28 / 77$ & 596 \\
\hline H03 & $15 \mathrm{~S}-26 \mathrm{E}-3 \mathrm{ccc}$ & $42^{\circ} 08.41^{\prime}$ & $113^{\circ} 24.69^{\prime}$ & 5,240 & 9/2/77-9/4/77 & 558 \\
\hline H05 & $15 \mathrm{~S}-26 \mathrm{E}-5 \mathrm{adb}$ & $42^{\circ} 08.95^{\prime}$ & $113^{\circ} 26.06^{\prime}$ & 5,500 & $9 / 14 / 77-10 / 12 / 77$ & 508 \\
\hline H02 & $15 \mathrm{~S}-26 \mathrm{E}-10 \mathrm{dca}$ & $42^{\circ} 07.68^{\prime}$ & $113^{\circ} 23.87^{\prime}$ & 5,060 & $8 / 21 / 77-8 / 22 / 77$ & 496 \\
\hline HF 1 & $15 \mathrm{~S}-26 \mathrm{E}-12 \mathrm{aaa}$ & $42^{\circ} 08.38^{\prime}$ & $113^{\circ} 21.26^{\prime}$ & 4,790 & & \\
\hline I.D. 1 & $15 \mathrm{~S}-26 \mathrm{E}-12 \mathrm{acb}$ & $42^{\circ} 08.08^{\prime}$ & $113^{\circ} 21.76^{\prime}$ & 4,850 & & \\
\hline HF 2 & $15 \mathrm{~S}-26 \mathrm{E}-13 \mathrm{bdc}$ & $42^{\circ} 07.23^{\prime}$ & $113^{\circ} 21.98^{\prime}$ & 4,840 & & \\
\hline H09 & $15 \mathrm{~S}-26 \mathrm{E}-15 \mathrm{dcc}$ & $42^{\circ} 06.72^{\prime}$ & $113^{\circ} 23.97^{\prime}$ & 5,020 & $10 / 13 / 77-10 / 15 / 77$ & 548 \\
\hline I.D. 3 & $15 \mathrm{~S}-26 \mathrm{E}-22 \mathrm{ddd}$ & $42^{\circ} 05.85^{\prime}$ & $113^{\circ} 23.60^{\prime}$ & 4,860 & & \\
\hline RRGE 2 & 15S-26E-23aаa & $42^{\circ} 06.65^{\prime}$ & $113^{\circ} 22.49^{\prime}$ & 4,840 & & \\
\hline SHW & $15 \mathrm{~S}-26 \mathrm{E}-23 \mathrm{bbc}$ & $42^{\circ} 06.48^{\prime}$ & $113^{\circ} 23.46^{\prime}$ & 4,924 & & \\
\hline RRGE 1 & $15 \mathrm{~S}-26 \mathrm{E}-23 \mathrm{caa}$ & $42^{\circ} 06.15^{\prime}$ & $113^{\circ} 23.00^{\prime}$ & 4,840 & & \\
\hline I.D. 2 & $15 \mathrm{~S}-26 \mathrm{E}-25 \mathrm{acb}$ & $42^{\circ} 05.56^{\prime}$ & $113^{\circ} 21.72^{\prime}$ & 4,840 & & \\
\hline RRGE 3 & $15 \mathrm{~S}-26 \mathrm{E}-25 \mathrm{bdc}$ & $42^{\circ} 05.49^{\prime}$ & $113^{\circ} 21.95^{\prime}$ & 4,850 & & \\
\hline HF 3 & $15 \mathrm{~S}-26 \mathrm{E}-25 \mathrm{ddd}$ & $42^{\circ} 04.96^{\prime}$ & $113^{\circ} 21.24^{\prime}$ & 4,860 & & \\
\hline HF 4 & $15 \mathrm{~S}-26 \mathrm{E}-27 \mathrm{bdc}$ & $42^{\circ} 05.40^{\prime}$ & $113^{\circ} 24.40^{\prime}$ & 4,880 & & \\
\hline H10 & 15S-26E-32bdd & $42^{\circ} 04.54^{\prime}$ & $113^{\circ} 26.52^{\prime}$ & 4,960 & $10 / 17 / 77-10 / 28 / 77$ & 508 \\
\hline $\mathrm{H} 30$ & $15 \mathrm{~S}-26 \mathrm{E}-32 \mathrm{bdd}$ & $42^{\circ} 04.54^{\prime}$ & $113^{\circ} 26.52^{\prime}$ & 4,960 & 11/7/77-11/14/77 & 900 \\
\hline HF 5 & $15 \mathrm{~S}-26 \mathrm{E}-33 \mathrm{acc}$ & $42^{\circ} 04.53^{\prime}$ & $113^{\circ} 25.25^{\prime}$ & 4,920 & & \\
\hline H18 & $15 \mathrm{~S}-27 \mathrm{E}-8 \mathrm{ddc}$ & $42^{\circ} 07.58^{\prime}$ & $113^{\circ} 19.02^{\prime}$ & 4,750 & $?-12 / 20 / 77$ & 484 \\
\hline H16 & $15 \mathrm{~S}-27 \mathrm{E}-11 \mathrm{cdc}$ & $42^{\circ} 07.58^{\prime}$ & $113^{\circ} 16.12^{\prime}$ & 4,910 & $12 / 4 / 77-12 / 14 / 77$ & 505 \\
\hline H01 & 15S-27E-30adc & $42^{\circ} 05.41^{\prime}$ & $113^{\circ} 20.15^{\prime}$ & 4,810 & 8/29/77-8/31/77 & 558 \\
\hline H15 & $15 \mathrm{~S}-27 \mathrm{E}-34 \mathrm{adc}$ & $42^{\circ} 04.54^{\prime}$ & $113^{\circ} 16.75^{\prime}$ & 4,910 & $11 / 18 / 77-12 / 15 / 77$ & 484 \\
\hline $\mathrm{H} 21$ & $16 \mathrm{~S}-25 \mathrm{E}-8 \mathrm{bcc}$ & $42^{\circ} 03.50^{\prime}$ & $113^{\circ} 34.10^{\prime}$ & 5,180 & $1 / 4 / 78-1 / 8 / 78$ & 483 \\
\hline H35 & $16 \mathrm{~S}-25 \mathrm{E}-12 \mathrm{bbc}$ & $42^{\circ} 03.83^{\prime}$ & $113^{\circ} 29.39^{\prime}$ & 5,040 & 1/10/78-1/15/78 & 433 \\
\hline $\mathrm{H} 41$ & 16S-25E-29aad & $42^{\circ} 01.18^{\prime}$ & $113^{\circ} 33.06^{\prime}$ & 5,400 & $1 / 11 / 78-1 / 17 / 78$ & 80 (126 TD) \\
\hline H14 & $16 \mathrm{~S}-26 \mathrm{E}-1 \mathrm{acc}$ & $42^{\circ} 03.65^{\prime}$ & $113^{\circ} 21.71^{\prime}$ & 4,980 & $11 / 17 / 77-12 / 6 / 77$ & 490 \\
\hline $\mathrm{H} 12$ & $16 \mathrm{~S}-26 \mathrm{E}-5 \mathrm{abb}$ & $42^{\circ} 03.97^{\prime}$ & $113^{\circ} 26.42^{\prime}$ & 5,000 & $11 / 30 / 77-12 / 2 / 77$ & 545 \\
\hline I.D. 4 & $16 \mathrm{~S}-26 \mathrm{E}-5 \mathrm{bba}$ & $42^{\circ} 04.02^{\prime}$ & $113^{\circ} 26.82^{\prime}$ & 4,960 & & \\
\hline H11 & $16 \mathrm{~S}-26 \mathrm{E}-5 \mathrm{ddb}$ & $42^{\circ} 03.32^{\prime}$ & $113^{\circ} 26.07^{\prime}$ & 5,100 & $10 / 30 / 77-11 / 2 / 77$ & 634 \\
\hline H13 & $16 \mathrm{~S}-26 \mathrm{E}-15 \mathrm{ccd}$ & $42^{\circ} 01.43^{\prime}$ & $113^{\circ} 24.50^{\prime}$ & 5,380 & $1116 / 77-12 / 3 / 77$ & 482 \\
\hline Strevell & $16 \mathrm{~S}-28 \mathrm{E}-20 \mathrm{cac}$ & $42^{\circ} 00.97^{\prime}$ & $113^{\circ} 12.47^{\prime}$ & 5,280 & & \\
\hline
\end{tabular}


Table 2. Calculated vertical velocities from flow model.

[Positive velocity is downward. Thermal conductivity value of 1.3 watt meter ${ }^{-1}{ }^{\circ} \mathrm{C}^{-1}$. Coefficient of determination $\mathrm{r}^{2}$ given for each fit]

\begin{tabular}{llcl}
\hline Well ID & $\begin{array}{c}\text { Depth range } \\
\text { (ft) }\end{array}$ & $\begin{array}{c}\text { Velocity } \\
(\mathbf{m} / \mathbf{y})\end{array}$ & $\mathbf{r}^{2}$ \\
\hline H01 & $125-546$ & 0.12 & 0.90 \\
H04 & $93-295$ & -0.026 & 0.77 \\
H11 & $155-401$ & 0.094 & 0.82 \\
H11 & $401-626$ & -0.23 & 0.83 \\
H12 & $195-517$ & -0.13 & 0.96 \\
H16 & $147-500$ & 0.072 & 0.88 \\
HF4 & $345-490$ & -0.16 & 0.87 \\
\hline
\end{tabular}

Table 3. Thermal conductivites, temperature gradients, and heat flow for wells at Raft River, Idaho. [Thermal conductivity in watts meter ${ }^{-1}{ }^{\circ} \mathrm{C}^{-1}$. Heat flow in milliwatts meter ${ }^{-2}$ ]

\begin{tabular}{|c|c|c|c|c|c|c|}
\hline Well ID & $\begin{array}{l}\text { Depth range } \\
\text { (ft) }\end{array}$ & 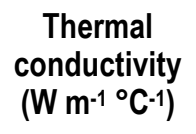 & $\begin{array}{l}\text { Standard deviation } \\
\left(\mathrm{W} \mathrm{m}^{-1}{ }^{\circ} \mathrm{C}^{-1}\right)\end{array}$ & $\begin{array}{l}\text { Depth range } \\
\text { (ft) }\end{array}$ & $\begin{array}{l}\text { Gradient } \\
\left({ }^{\circ} \mathrm{C} / \mathrm{km}\right)\end{array}$ & $\begin{array}{l}\text { Heat flow } \\
\left(\mathrm{mW} / \mathrm{m}^{2}\right)\end{array}$ \\
\hline I.D. 1 & $293-1100$ & 1.08 & 0.15 & $345-605$ & 136.7 & 148 \\
\hline I.D. 2 & $257-786$ & 1.30 & 0.29 & $75-590$ & 214.9 & 279 \\
\hline I.D. 3 & $212-1328$ & 1.68 & 0.43 & $116-884$ & 235.9 & 396 \\
\hline \multirow[t]{3}{*}{ I.D. 5} & $114-392$ & 1.87 & 0.23 & 189-395 & 61.9 & 116 \\
\hline & $405-658$ & 2.38 & 0.36 & $500-716$ & 44.2 & 105 \\
\hline & $114-658$ & 2.10 & 0.39 & & & \\
\hline
\end{tabular}


Table 4. Representative temperature gradients for wells at Raft River, Idaho.

[Depths and temperatures used to calculate gradients are given]

\begin{tabular}{|c|c|c|c|c|c|}
\hline Well ID & $\begin{array}{c}\text { Depth } \\
\text { (ft) }\end{array}$ & $\begin{array}{l}\text { Temperature } \\
\left({ }^{\circ} \mathrm{C}\right)\end{array}$ & $\begin{array}{c}\text { Depth } \\
\text { (ft) }\end{array}$ & $\begin{array}{c}\text { Temperature } \\
\left({ }^{\circ} \mathrm{C}\right)\end{array}$ & $\begin{array}{l}\text { Gradient } \\
\left({ }^{\circ} \mathrm{C} / \mathrm{km}\right)\end{array}$ \\
\hline SHW & 106 & 50.859 & 312 & 79.12 & 450.1 \\
\hline I.D. 1 & 345 & 20.605 & 605 & 31.441 & 136.7 \\
\hline I.D. 2 & 75 & 17.481 & 590 & 51.213 & 214.9 \\
\hline I.D. 3 & 116 & 22.861 & 884 & 78.086 & 235.9 \\
\hline I.D. 4 & 24 & 35.618 & 42 & 39.867 & 774.5 \\
\hline \multirow[t]{2}{*}{ I.D. 5} & 189 & 15.078 & 395 & 18.967 & 61.9 \\
\hline & 500 & 20.614 & 716 & 23.523 & 44.2 \\
\hline \multirow[t]{2}{*}{ I.D. $5 \mathrm{~A}$} & 165 & 14.474 & 407 & 19.213 & 64.3 \\
\hline & 500 & 20.668 & 1194 & 30.163 & 44.9 \\
\hline Strevell & 215 & 13.147 & 685 & 21.242 & 56.5 \\
\hline Almo 1 & 36 & 35.824 & 82 & 53.305 & 1246.9 \\
\hline Almo 2 & 155 & 12.921 & 630 & 20.145 & 49.9 \\
\hline \multirow[t]{2}{*}{ Griffith-Wight } & 655 & 33.167 & 1285 & 43.863 & 55.7 \\
\hline & 4260 & 85.001 & 4710 & 92.359 & 53.6 \\
\hline RRGE 1 & 325 & 53.334 & 630 & 76.188 & 245.8 \\
\hline RRGE 2 & 289 & 54.339 & 1072 & 77.41 & 96.7 \\
\hline RRGE 3 & 310 & 45.13 & 480 & 66.192 & 406.5 \\
\hline HF1 & 79 & 14.569 & 415 & 27.05 & 121.9 \\
\hline HF2 & 57 & 13.641 & 172 & 19.186 & 158.2 \\
\hline HF3 & 91 & 15.439 & 484 & 31.816 & 136.7 \\
\hline HF4 & 44 & 14.263 & 340 & 26.659 & 137.4 \\
\hline \multirow[t]{2}{*}{ HF5 } & 122 & 13.587 & 308 & 18.116 & 79.9 \\
\hline & 333 & 18.923 & 482 & 23.888 & 109.3 \\
\hline \multirow[t]{3}{*}{ H01 } & 62 & 10.36 & 143 & 10.637 & 11.2 \\
\hline & 483 & 15.124 & 515 & 15.873 & 76.8 \\
\hline & 80 & 10.384 & 552 & 16.934 & 45.5 \\
\hline \multirow[t]{2}{*}{ H02 } & 60 & 13.166 & 252 & 18.286 & 87.5 \\
\hline & 288 & 19.29 & 472 & 23.673 & 78.2 \\
\hline \multirow[t]{3}{*}{ H03 } & 80 & 11.703 & 210 & 13.904 & 55.5 \\
\hline & 348 & 16.846 & 420 & 18.371 & 69.5 \\
\hline & 440 & 18.835 & 508 & 20.81 & 95.3 \\
\hline \multirow[t]{2}{*}{ H04 } & 76 & 12.928 & 240 & 16.526 & 72.0 \\
\hline & 329 & 18.209 & 653 & 23.409 & 52.7 \\
\hline \multirow[t]{2}{*}{ H05 } & 58 & 11.802 & 480 & 19.053 & 56.4 \\
\hline & 488 & 19.181 & 500 & 19.823 & 175.5 \\
\hline
\end{tabular}




\begin{tabular}{|c|c|c|c|c|c|}
\hline Well ID & $\begin{array}{l}\text { Depth } \\
\text { (ft) }\end{array}$ & $\begin{array}{c}\text { Temperature } \\
\left({ }^{\circ} \mathrm{C}\right)\end{array}$ & $\begin{array}{l}\text { Depth } \\
\text { (ft) }\end{array}$ & $\begin{array}{c}\text { Temperature } \\
\left({ }^{\circ} \mathrm{C}\right)\end{array}$ & $\begin{array}{l}\text { Gradient } \\
\left({ }^{\circ} \mathrm{C} / \mathrm{km}\right)\end{array}$ \\
\hline \multirow[t]{2}{*}{ H06 } & 36 & 11.497 & 116 & 14.016 & 103.3 \\
\hline & 184 & 15.219 & 264 & 17.424 & 90.4 \\
\hline H07 & 88 & 13.472 & 560 & 26.277 & 89.0 \\
\hline H08 & 90 & 12.579 & 462 & 19.946 & 65.0 \\
\hline H09 & 118 & 18.173 & 227 & 25.038 & 206.6 \\
\hline H10 & 29 & 16.486 & 150 & 46.544 & 815.0 \\
\hline \multirow[t]{2}{*}{ H11 } & 183 & 13.288 & 334 & 18.713 & 117.9 \\
\hline & 378 & 20.821 & 619 & 28.145 & 99.7 \\
\hline \multirow[t]{2}{*}{ H12 } & 58 & 14.095 & 171 & 19.992 & 171.2 \\
\hline & 199 & 21.496 & 515 & 28.761 & 75.4 \\
\hline \multirow[t]{3}{*}{ H13 } & 218 & 13.742 & 301 & 14.966 & 48.4 \\
\hline & 322 & 15.423 & 437 & 18.83 & 97.2 \\
\hline & 86 & 11.056 & 464 & 19.439 & 72.8 \\
\hline H14 & 140 & 11.702 & 314 & 14.687 & 56.3 \\
\hline H15 & 248 & 11.299 & 448 & 14.018 & 44.6 \\
\hline \multirow[t]{3}{*}{ H16 } & 146 & 10.934 & 245 & 11.857 & 30.6 \\
\hline & 324 & 12.87 & 498 & 15.679 & 53.0 \\
\hline & 122 & 10.776 & 505 & 15.812 & 43.1 \\
\hline \multirow[t]{2}{*}{ H17 } & 103 & 10.938 & 201 & 12.227 & 43.2 \\
\hline & 302 & 13.89 & 487 & 17.605 & 65.9 \\
\hline H18 & 210 & 12.371 & 470 & 17.744 & 67.8 \\
\hline \multirow[t]{2}{*}{ H19 } & 145 & 15.529 & 222 & 16.772 & 53.0 \\
\hline & 311 & 17.789 & 463 & 17.935 & 3.2 \\
\hline \multirow[t]{2}{*}{$\mathrm{H} 21$} & 122 & 10.645 & 246 & 12.61 & 52.0 \\
\hline & 261 & 12.928 & 405 & 16.838 & 89.1 \\
\hline $\mathrm{H} 22$ & 88 & 10.787 & 236 & 12.241 & 32.2 \\
\hline H30 & 45 & 24.377 & 152 & 51.114 & 819.9 \\
\hline H35 & 244 & 22.007 & 413 & 30.454 & 164.0 \\
\hline H41 & 62 & 9.644 & 90 & 9.976 & 38.9 \\
\hline
\end{tabular}

Menlo Park Publishing Service Center, California

Manuscript approved for publication September 12, 2014

Text edited by Peter H. Stauffer

Design and layout by Cory D. Hurd 